\title{
Position of the Polar Front along the western Iberian margin during key cold episodes of the last $45 \mathrm{ka}$
}

\section{Frédérique Eynaud}

EPOC, UMR 5805, Université Bordeaux 1, Avenue des Facultés, F-33405 Talence, France

(f.eynaud@epoc.u-bordeaux1.fr)

Lúcia de Abreu and Antje Voelker

Departamento de Geologia Marinha, LNEG, Estrada da Portela, 2721-866 Zambujal, Portugal

Also at CIMAR Associate Laboratory, 4050-123 Porto, Portugal.

\section{Joachim Schönfeld}

Leibniz Institute of Marine Sciences at University of Kiel (IFM-GEOMAR), Wischbofstrasse 1-3, D-24148 Kiel, Germany

\section{Emilia Salgueiro}

Departamento de Geologia Marinha, LNEG, Estrada da Portela, 2721-866 Zambujal, Portugal

Also at CIMAR Associate Laboratory, 4050-123 Porto, Portugal.

Jean-Louis Turon, Aurélie Penaud, and Samuel Toucanne

EPOC, UMR 5805, Université Bordeaux 1, Avenue des Facultés, F-33405 Talence, France

\section{Filipa Naughton}

Departamento de Geologia Marinha, LNEG, Estrada da Portela, 2721-866 Zambujal, Portugal

María Fernanda Sánchez Goñi and Bruno Malaizé

EPOC, UMR 5805, Université Bordeaux 1, Avenue des Facultés, F-33405 Talence, France

\section{Isabel Cacho}

Departament d'Estratigrafia, Paleontologia i Geociències Marines, Facultat de Geologia, University of Barcelona, Diagonal Sud, c/Martí Franques s/n, E-08028 Barcelona, Spain

[1] This paper documents the migration of the Polar Front (PF) over the Iberian margin during some of the cold climatic extremes of the last $45 \mathrm{ka}$. It is based on a compilation of robust and coherent paleohydrological proxies obtained from eleven cores distributed between 36 and $42^{\circ} \mathrm{N}$. Planktonic $\delta^{18} \mathrm{O}$ (Globigerina bulloides), ice-rafted detritus concentrations, and the relative abundance of the polar foraminifera Neogloboquadrina pachyderma sinistral were used to track the PF position. These three data sets, compared from core to core, show a consistent evolution of the sea surface paleohydrology along the Iberian margin over the last $45 \mathrm{ka}$. We focused on five time slices representative of cold periods under distinct paleoenvironmental forcings: the $8.2 \mathrm{ka}$ event and the Younger Dryas (two recent cold events occurring within high values of summer insolation), Heinrich events 1 and 4 (reflecting major episodes of massive iceberg discharges into the North Atlantic), and the Last Glacial Maximum (typifying the highest ice volume accumulated in the Northern Hemisphere). For each event, we generated schematic maps 
mirroring past sea surface hydrological conditions. The maps revealed that the Polar Front presence along the Iberian margin was restricted to Heinrich events. The sea surface conditions during the Last Glacial Maximum were close to those at present day, except for the northern sites which briefly experienced subarctic conditions.

Components: 12,726 words, 5 figures, 4 tables.

Keywords: Polar Front; LGM; Heinrich events.

Index Terms: 0473 Biogeosciences: Paleoclimatology and paleoceanography (3344, 4900); 4901 Paleoceanography: Abrupt/rapid climate change (1605); 4926 Paleoceanography: Glacial; 4960 Paleoceanography: Stadial; 1635 Global Change: Oceans $(1616,3305,4215,4513)$.

Received 26 January 2009; Revised 6 May 2009; Accepted 8 May 2009; Published 1 July 2009.

Eynaud, F., et al. (2009), Position of the Polar Front along the western Iberian margin during key cold episodes of the last 45 ka, Geochem. Geophys. Geosyst., 10, Q07U05, doi:10.1029/2009GC002398.

Theme: Circum-Iberia Paleoceanography and Paleoclimate: What Do We Know?

Guest Editors: F. Abrantes, C. Ruehlemann, M. F. Sánchez Goñi, and A. Voelker

\section{Introduction}

[2] For more than 2.5 Ma, the Earth has experienced drastic climatic fluctuations among which the more pronounced occurred during the last $450 \mathrm{ka}$. Forcing factors at the origin of these major climatic seesaws are now fairly well identified throughout external (orbital) and internal parameters of the Earth's climatic system. However, phasing relationship and coupling phenomena between these parameters are still not well understood [e.g., Lisiecki et al., 2008]. In this way, climate extremes are major challenges regarding our comprehension of the Earth's climate variability and stability. The abrupt cold excursions, i.e., stadial events [Dansgaard et al., 1993] or Heinrich events [Heinrich, 1988], which occurred during the last glacial period, provide excellent archives of Pleistocene rapid climatic transitions. They, furthermore, raise major questions about the pace of the natural system. The extreme Heinrich events result from a massive calving of icebergs in relation to the sudden collapse of the periarctic ice sheets during the last glacial period [e.g., Heinrich, 1988; Bond et al., 1993; Hemming, 2004]. They took place at the end of a sawtooth shaped cooling cycle of 4 successive stadials/interstadials (e.g., Bond cycles [Bond et al., 1993]). However, the triggering of these events is still a matter of debate, as they imply complex mechanisms linking ice sheet, atmosphere and ocean dynamics. Their impact was recognized worldwide [e.g., Leuschner and Sirocko, 2000; Wang et al., 2001] and each of the Earth's surface reservoirs, i.e., the cryosphere, atmosphere, oceans, and biosphere, was affected. Some of the most severe Heinrich events impacted dramatically on the North Atlantic's overturning circulation [e.g., Zahn et al., 1997; Curry et al., 1999; Roche et al., 2004]. These events potentially constitute catastrophic analogs of modern or nearfuture ice sheet (Antarctic especially) collapses in the context of global warming.

[3] The objective of this paper is to document the impact of some of these cold extremes on the surface water hydrology of the Iberian margin. For this purpose, we focus on the reconstruction of the position of the Polar Front over the last 45 cal ka B.P. (calibrated ${ }^{14} \mathrm{C}$ kiloyears before present; hereafter referred to as "ka"). We selected five time slices (Table 2a in section 2.2) representative of well-known cold episodes under various climatic forcing mechanisms (insolation, continental ice storage, sea level values, vegetation cover). At Present, the Polar Front (PF) closely follows the Greenland and eastern Canadian continental margins (Figure 1). In the ocean it is defined as a physical oceanographic structure with high temperature and salinity gradients, which separates two different surface water masses: the relatively warm, high-salinity Atlantic Water, and the cold lowsalinity modified Polar Water carried southward by the East and West Greenland and Labrador currents [Holliday et al., 2007]. This front constitutes a strong ecological barrier in the North Atlantic Ocean and also physically constrains sea ice and iceberg drifting. The latitudinal migration 

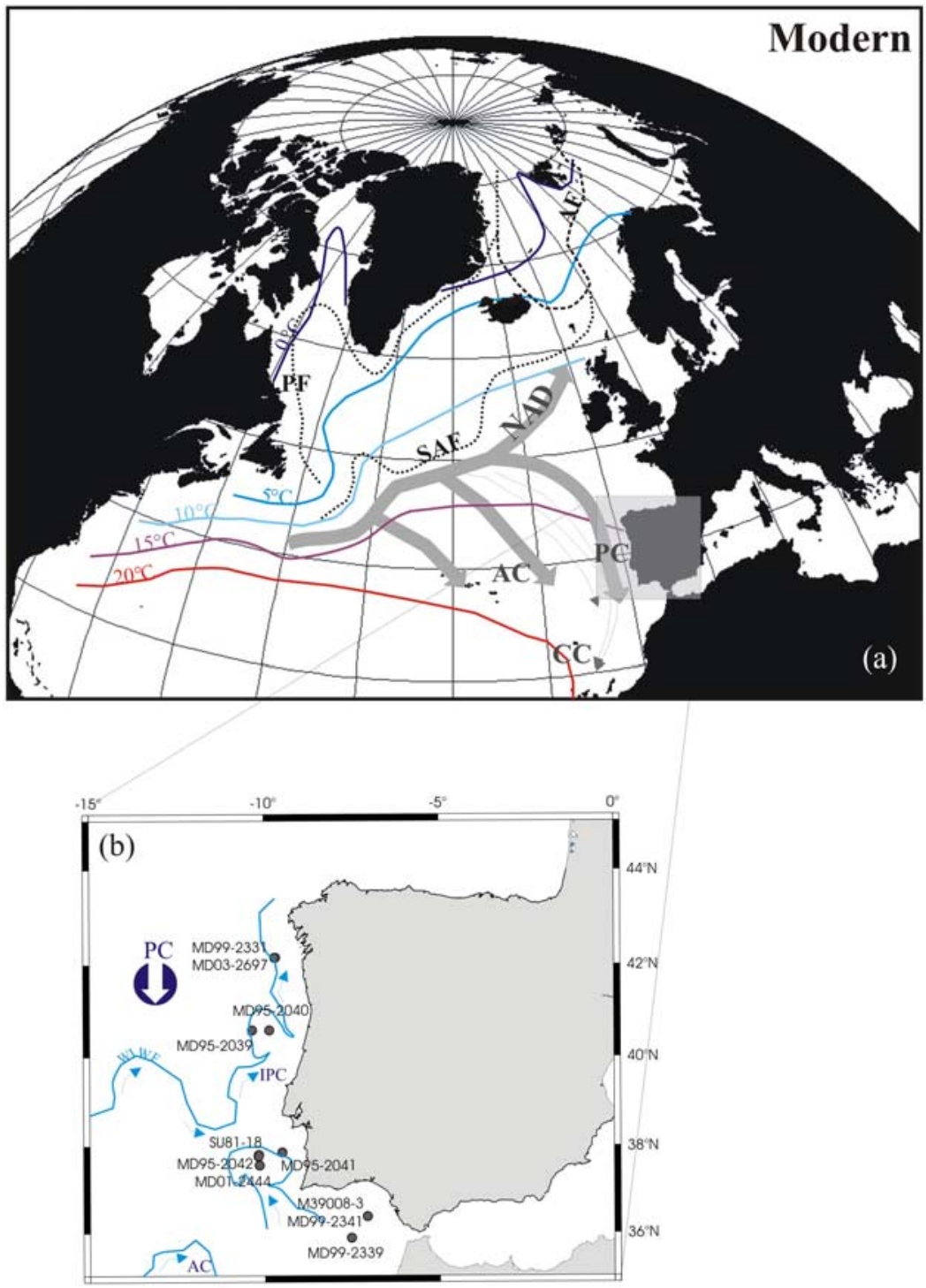

Figure 1. (a) Modern sea surface hydrographic conditions of the North Atlantic Ocean. Schematic pathway of the North Atlantic Drift (NAD) and its major boundary return currents (PC, Portugal Current; CC, Canary Current; AC, Azores Current) [after Sverdrup et al., 1942; Crowley, 1981; Dickson et al., 1988]. The SST isotherms are from Tchernia [1978] (SST annual mean). Dotted lines locate the major hydrographic fronts: PF, Polar Front; AF, Arctic Front; SAF, Subarctic Front [after Dickson et al., 1988]. (b) Location of the studied cores along the Iberian margin with regard to the modern sea surface structures in winter (PC, Portugal Current; IPC, Iberian Poleward Current; AC, Azores Current; WIWF, Western Iberia Winter Front [after Peliz et al., 2005]).

of the Polar Front as south as $40^{\circ} \mathrm{N}$ during late Pleistocene cold events has been documented by numerous studies [e.g., McIntyre et al., 1976; Ruddiman and McIntyre, 1981; Duprat, 1983; Bard et al., 1987; Abrantes et al., 1998]. Our intention is to complement this information, since the Iberian margin offers by now an exceptional coverage of high-quality sequences, i.e., with diversified data sets, high time resolution and excellent stratigraphical control (Table 1). We choose robust paleohydrological proxies, i.e., planktonic $\delta^{18} \mathrm{O}$ (in Globigerina bulloides), ice-rafted detritus (IRD) concentrations and the relative abundance of the polar foraminifera Neogloboquadrina pachyderma sinistral (left coiled, $N$. pachyderma sinistral). These data sets were readily compared from core to core. They allowed us to create regional maps and estimate past changes in sea surface hydrology displaying the migration of the PF with 
Table 1. Geographic Information of the Selected Cores

\begin{tabular}{lcccc}
\hline \multicolumn{1}{c}{ Core } & Latitude & Longitude & Water Depth $(\mathrm{m})$ & Core Length (m) \\
\hline SU81-18 & 37.767 & -10.183 & 3155 & 7 \\
MD95-2039 & 40.580 & -10.350 & 3381 & 35.71 \\
MD95-2040 & 40.580 & -9.860 & 2465 & 35.24 \\
MD95-2041 & 37.883 & -9.510 & 1123 & 17.62 \\
MD95-2042 & 37.800 & -10.170 & 3146 & 39.56 \\
MD99-2331 & 42.150 & -9.683 & 2120 & 37.20 \\
MD99-2339 & 35.886 & -7.528 & 1177 & 18.54 \\
MD99-2341 & 36.389 & -7.066 & 582 & 19.42 \\
MD01-2444 & 37.561 & -10.150 & 2642 & 27.48 \\
MD03-2697 & 42.150 & -9.700 & 2164 & 41.23 \\
M39008-3 & 36.380 & -7.072 & 577 & 5.8 \\
\hline
\end{tabular}

a far better resolution than had been previously possible.

\section{Iberian Margin}

\subsection{Present-Day Hydrography}

\subsubsection{Dynamic Features}

[4] The hydrography at the western Iberian margin (Figure 1) is primarily influenced by the North Atlantic subtropical gyre dynamic and a complex current system [Relvas et al., 2007]. The surface circulation regime is governed by the seasonal displacement of the Azores anticyclonic cell and its associated winds [e.g., Fiúza, 1984; Fiúza et al., 1998]. Several major features have to be considered; they are described in sections 2.1.1.1-2.1.1.3.

\subsubsection{Large-Scale Currents}

[5] These include (1) the Portugal Current (PC), flowing southward from $45^{\circ} \mathrm{N}$ to $30^{\circ} \mathrm{N}$; (2) the Azores Current (AC) derived from the southern branch of the Gulf Stream (GS) and flowing eastward to the Gulf of Cadiz at about $38^{\circ} \mathrm{N}$; and (3) the Canary Current (CC) which is fed by both the $\mathrm{AC}$ and the PC. Together, these currents form the Eastern Boundary Current of the subtropical gyre.

\subsubsection{Portugal Upwelling System}

[6] The western Iberian margin belongs to the Portugal-Canary eastern boundary upwelling system [Peliz et al., 2005]. Between April and October, upwelling cells are activated in response to strong northerlies which accompany the northward displacement and the strengthening of the Azores high-pressure cell [Fiúza et al., 1982; Fiúza, 1984; Sousa and Bricaud, 1992; Sánchez and Relvas, 2003]. This leads to the formation of a cold and nutrient-rich coastal water band [Relvas et al., 2007], which may extend from between 30 and $50 \mathrm{~km}$ and 100-200 km offshore [e.g., Sousa and Bricaud, 1992; Relvas et al., 2007]. Eastern North Atlantic Central Water (ENACW) and partially Mediterranean Outflow Water [Sánchez and Relvas, 2003] are the sources of the upwelled waters.

\subsubsection{Iberian Poleward Current}

[7] During winter months, weak northerlies interspersed occasionally with strong south-southwest winds, favoring coastal convergence conditions. The most relevant transport mechanism is then the northward flow of a warm surface and undercurrent denominated as the Iberian Poleward Current (IPC) or Portugal Coastal Counter Current [e.g., Fiúza et al., 1998; Peliz et al., 2005] (Figure 1b). This current is recognized northward up to the Bay of Biscay, where it is known as the "Navidad Current" [Garcia-Soto et al., 2002]. The poleward flow affects both the surface and intermediate waters down to $1500 \mathrm{~m}$ depth [Relvas et al., 2007], adding warm and saline inputs into the study region [Haynes and Barton, 1990]. A connection with a northward recirculation of the $\mathrm{AC}$ has also been suggested [Peliz et al., 2005].

\subsubsection{Synoptic View}

[8] Modern sea surface conditions (Figure 1) along the margin between $37^{\circ}$ and $41^{\circ} \mathrm{N}$ are characterized by mean annual temperatures ranging from $18^{\circ} \mathrm{C}$ to $16^{\circ} \mathrm{C}$ [Levitus, 1994]. These isotherms move seasonally and zonal gradients may occur during some periods of the year [Peliz et al., 2005]. During winter the Western Iberia Winter Front (WIWF), a recurrent feature between 10 and $11^{\circ} \mathrm{W}$, separates the subtropical IPC waters from the cooler PC around $40^{\circ} \mathrm{N}$ [Peliz et al., 2005] (Figure 1b). However, major features are generated with the 
summer upwelling: a marked cold coastal band occurs, where the SST anomaly could reach an amplitude of $-5^{\circ} \mathrm{C}$ (averaged values from JuneSeptember 2001-2005 [Relvas et al., 2007]).

[9] Intermediate circulation is dominated by the ENACW and the Mediterranean Outflow Water (MOW). Two main MOW branches are distinguishable, an upper core centered around 700$800 \mathrm{~m}$, and a lower core at about $1200 \mathrm{~m}$ [Ambar and Howe, 1979; Iorga and Lozier, 1999]. The MOW follows a poleward route, but also propagates toward the west in the form of "meddies." This water mass is supposed to have a dynamic impact regarding the ocean upper layers and it may notably constitute a complementary contributor to the AC [Jia, 2000].

\subsection{Past Protrusions of Polar Waters}

[10] Figure 2 presents the state of the art regarding mapping of past incursions of Polar waters in the North Atlantic for the Last Glacial Maximum (LGM [CLIMAP Project Members, 1981; Kucera et al., 2005a]) (Figure 2a) and for Heinrich events (HEs [Ruddiman, 1977; Cortijo et al., 2005]) (Figure 2b). It is worth noting that existing maps diverge regarding the kind of structure represented. This mismatch does not favor an objective representation of the events. In fact, the quality and resolution of the existing maps are linked to the proxies used for their construction, for instance the maximum abundances of lithics grains in the sediment [e.g., Hemming, 2004], $\delta^{18} \mathrm{O}$ isolines for HEs [e.g., Cortijo et al., 2005], or seasonal sea ice limit for the LGM [e.g., CLIMAP Project Members, 1981; Kucera et al., 2005a; Byrkjedal et al., 2006]. They furthermore show poor details along the North Atlantic margins. This is especially true for the Iberian Margin despite the fact that this region was the focus of numerous paleoceanographic investigations, and that its sensitivity to abrupt climatic changes was recognized early [e.g., Turon, 1984; Bard et al., 1987; Zahn et al., 1997; Abrantes et al., 1998; Shackleton et al., 2000; Martrat et al., 2004, 2007].

[11] For the last glacial period, the southernmost latitudinal position of the Polar Front (PF) in the North Atlantic Ocean was initially drawn around $40^{\circ} \mathrm{N}$ [CLIMAP Project Members, 1981; Ruddiman and McIntyre, 1981; Bard et al., 1987] (Figure 2a). High-resolution studies revealed, however, contrasting hydrological patterns between the LGM interval (time slice: 19-23 ka B.P. in the sense of Mix et al. [2001]) and the surrounding HEs [e.g.,
Sarnthein et al., 1995, 2003; de Vernal et al., 2000]. Along the Iberian margin, this was first demonstrated by Abrantes et al. [1998], who compared the last $20 \mathrm{ka}$ paleohydrology of six ENAM (European North Atlantic Margin) sites in between the Nordic seas and the Portuguese margin and concluded that the Polar Front did not reach the Iberian margin during the LGM. Instead, their SST reconstructions revealed the installation of hydrological conditions similar to those of the Holocene at that time. This was later corroborated by further studies also based on planktonic foraminifera [de Abreu et al., 2003; Kucera et al., 2005b]. Similar to the Younger Dryas [Bard et al., 1987], the most drastic hydrological changes along the Iberian margin were recorded during major glacial collapses, i.e., HEs [Abrantes et al., 1998], with a southward influence of icebergs testified up to $37^{\circ} \mathrm{N}$ and beyond [Kudrass, 1973; Schönfeld and Zahn, 2000; Cacho et al., 2001].

[12] In the "Ruddiman" IRD belt Heinrich layers are easily identified in deep-sea sediments as layers of coarse lithic grains, repetitively deposited over the last $70 \mathrm{ka}$ [e.g., Heinrich, 1988; Bond et al., 1993; Grousset et al., 1993; Hemming et al., 1998]. The HEs also carry a strong micropaleontological signal there, with planktonic foraminifera assemblages becoming dominated by the polar species $N$. pachyderma sinistral, and a geochemical signature preserved in the polar foraminifera tests showing lightening in the surface water oxygen isotopic ratio due to the input of freshwater [Vidal et al., 1997; Elliot et al., 1998; Cortijo et al., 2005] (Figure 2b). Although the impact of HEs on the Iberian margin and adjacent continents has been recognized throughout different multiproxy studies as far south as $36^{\circ} \mathrm{N}$ [Bard et al., 1987; Lebreiro et al., 1996; Baas et al., 1997, 1998; Zahn et al., 1997; Abrantes et al., 1998; Bard et al., 2000; Sánchez Goñi et al., 2000; Thouveny et al., 2000; Schönfeld et al., 2003; de Abreu et al., 2003; Roucoux et al., 2001, 2005; Voelker et al., 2006; Narciso et al., 2006; Naughton et al., 2007, 2009; F. Naughton et al., Wet to dry climatic trend in north western Iberia within Heinrich events, paper presented at IX International Conference on Paleoceanography, Shanghai, China, September 2007], and over several climatic cycles [Sánchez Goñi et al., 1999; Eynaud et al., 2000; Moreno et al., 2002; Martrat et al., 2007], a discussion still exists whether or not large icebergs have prevailed in the seas off western Iberia. Diverse works have actually debated how to tackle the problem of what is purely ice-rafted material and what can be 

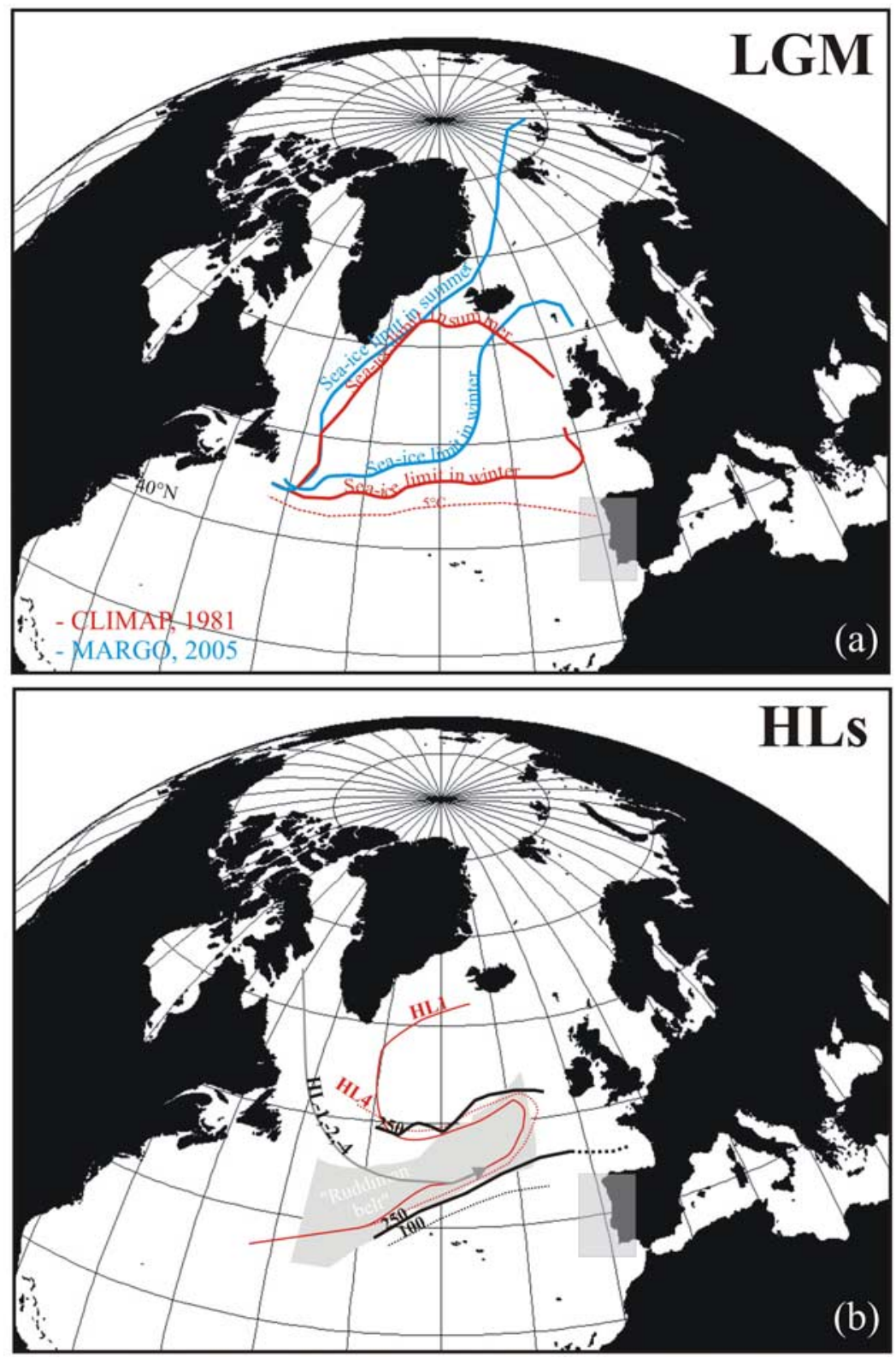

Figure 2. Past sea surface hydrographic conditions of the North Atlantic Ocean. (a) During the Last Glacial Maximum. Northern limit of ice-free conditions during winter and summer after CLIMAP Project Members [1981] (red lines) and after Kucera et al. [2005a] (blue lines). The $5^{\circ} \mathrm{C} \mathrm{SST}$ isotherm in winter after CLIMAP is also indicated. (b) During Heinrich events. Ice-rafted detritus (IRD) belt or "Ruddiman belt" in gray with the 250 and $100 \mathrm{mg} \mathrm{cm} \mathrm{ka}^{-1}$ flux lines [after Ruddiman, 1977; Hemming, 2004]. Preferential routing of icebergs during HE1, HE2, and HE4 [after Grousset et al., 1993]. Planktonic $\delta^{18} \mathrm{O} 1 \%$ isoline for HE4 (dotted red line) and HE1 (full red line) [after Cortijo et al., 2005].

continent/platform-derived in this high-sedimentation margin [e.g., Baas et al., 1997; Zahn et al., 1997; Bard et al., 2000; Toucanne et al., 2007]. In fact, in this area heavier planktonic $\delta^{18} \mathrm{O}$ values confirm colder SST rather than ice melting, as they consistently did during Dansgaard-Oeschger (DO) stadials [Shackleton et al., 2000], in agreement with other SST indicators like foraminifera and dinocyst assemblages [e.g., de Abreu et al., 2003; Schönfeld et al., 2003; Turon et al., 2003], alkenone concentrations [e.g., Pailler and Bard, 2002; Cacho et al., 2001] and $\mathrm{Mg} / \mathrm{Ca}$ [Skinner and Elderfield, 2005]. HEs, nevertheless, represent times of major protrusion of less saline polar waters on this margin as indicated by the cooccurrence of colder surface waters and ice-rafted 
Table 2a. Stratigraphical Intervals of the Events Considered in This Paper ${ }^{\mathrm{a}}$

\begin{tabular}{|c|c|c|c|c|c|c|c|c|c|}
\hline \multirow[b]{2}{*}{ Event } & $8.2 \mathrm{ka}^{\mathrm{b}}$ & \multicolumn{2}{|c|}{$\mathrm{YD}^{\mathrm{c}}$} & \multicolumn{2}{|c|}{$\mathrm{HE} 1^{\mathrm{d}}$} & \multicolumn{2}{|c|}{$\mathrm{LGM}^{\mathrm{e}}$} & \multicolumn{2}{|c|}{$\mathrm{HE} 4^{\mathrm{f}}$} \\
\hline & ${ }^{14} \mathrm{C}$ ka B.P. cal ka B.P. & ${ }^{14} \mathrm{C}$ ka B.P & P. cal ka B.P. & ${ }^{14} \mathrm{C}$ ka B.P. & cal ka B.P. & ${ }^{14} \mathrm{C}$ ka B.P & cal ka B.P. & ${ }^{14} \mathrm{C}$ ka B.P. & cal ka B.P. \\
\hline TOP & 8.0 & 10 & 11.5 & 13.4 & 15 & 16 & 19 & 33.9 & 38.5 \\
\hline BASE & 8.6 & 11 & 13 & 15.1 & 18 & 19.5 & 23 & 34.9 & 40 \\
\hline
\end{tabular}

${ }^{\mathrm{a}}$ The ages of these intervals were reported from the most cited bibliographic sources dealing with the selected events.

${ }^{\mathrm{b}}$ Limits after Rohling and Pälike [2005].

${ }^{\mathrm{c}}$ Limits after Bard [1998].

${ }^{\mathrm{d}}$ The ${ }^{14} \mathrm{C}$ limits after Elliot et al. [1998, 2001] and CAL limits after Bard et al. [2000].

${ }^{\mathrm{e}}$ LGM EPILOG definition in the sense of Mix et al. [2001].

${ }^{\mathrm{f}}$ The ${ }^{14} \mathrm{C}$ limits after Elliot et al. [1998, 2001] and CAL limits after Sánchez Goñi et al. [2000].

debris (IRD [e.g., Lebreiro et al., 1996; Bard et al., 2000; Moreno et al., 2002; de Abreu et al., 2003]). The strong cooling in the surface waters overprinted the salinity signal (freshening due to iceberg melting) in the planktonic $\delta^{18} \mathrm{O}$ values.

[13] For this paper, we focused on 5 time slices representative of well-dated cold events in the Northern Hemisphere (Tables 2a and 2b), but which were characterized by distinct orbital configuration, atmospheric $\mathrm{pCO}_{2}$ concentration, ice sheet extension, and vegetation cover. They are as follows:

[14] 1. Heinrich event 4 (HE4) is one of the most pronounced events regarding IRD fluxes [Cortijo et al., 1997, 2005; Schönfeld et al., 2003; Hemming, 2004], also marked by a nearly complete shutdown of the thermohaline circulation [Maslin et al., 1995; Elliot et al., 2002; Roche et al., 2004]. Decreasing summer insolation values $\left(65^{\circ} \mathrm{N}\right)$ characterize this interval.

[15] 2. The LGM is the time of the most recent maximum in globally integrated ice volume and minimum in global sea level [Mix et al., 2001]. The temperate forests were substantially fragmented and reduced in extent at that time, in a context of dryer and colder midlatitude climate [e.g., Harrison et al., 2001; Harrison and Prentice, 2003; Roucoux et al., 2005; Naughton et al., 2007]. Marine proxies suggest significantly colder than modern sea surface conditions in some domains of the North Atlantic, with a seasonal SST contrast larger than at present [de Vernal et al., 2005, 2006]. Also, a more zonal temperature pattern existed, with a steep $10^{\circ} \mathrm{C} \mathrm{SST}$ gradient between 40 and $45^{\circ} \mathrm{N}$ [Duprat, 1983; Calvo et al., 2001; de Vernal et al., 2006]. The LGM was marked by a summer insolation at high latitudes with values similar to today.

[16] 3. Heinrich event 1 (HE1) is the last known major ice sheet collapse [Heinrich, 1988; Dowdeswell et al., 1995; Cortijo et al., 2005], and it coincides with the onset of the last termination and times of major climate reorganization toward modern conditions [Steffensen et al., 2008]. HE1 occurred in a context of increasing insolation. On the European margin, this event shows a double signature, with a first impact of European ice sheet melting (precursor events), followed by the Laurentide ice sheet collapse imprint [e.g., Grousset et al., 2000; Zaragosi et al., 2001; Peck et al., 2007].

Table 2b. Dates Obtained After Previous Works on the Iberian Margin for Heinrich Events ${ }^{\mathrm{a}}$

\begin{tabular}{|c|c|c|c|c|c|}
\hline \multicolumn{3}{|c|}{ HE1 Along the Iberian Margin (cal ka B.P.) } & \multicolumn{3}{|c|}{ HE4 Along the Iberian Margin (cal ka B.P.) } \\
\hline Top & Base & Cores/References & Top & Base & Cores/Reference \\
\hline 14.85 & 17.64 & $\begin{array}{l}\text { MD95-2039 (Schönfeld et al. [2003]: } \\
\text { after N. pachyderma sinistral \%) }\end{array}$ & & & \\
\hline 14.96 & 17.84 & $\begin{array}{l}\text { MD95-2040 (Schönfeld et al. [2003] } \\
\text { and de Abreu et al. [2003]: } \\
\text { after N. pachyderma sinistral \%) }\end{array}$ & 37.95 & 39.93 & $\begin{array}{l}\text { MD95-2040 (Schönfeld et al. [2003]: } \\
\text { after N. pachyderma sinistral \%) }\end{array}$ \\
\hline 15.04 & 17.44 & $\begin{array}{l}\text { SU81-18 (Bard et al. [2000]: } \\
\text { 255-330 cm after alkenone record } \\
\text { and main IRD concentrations) }\end{array}$ & & & \\
\hline 15.38 & 17.17 & MD99-2339 (Voelker et al. [2006]: SST) & 38.5 & 39.5 & MD99-2339 (Voelker et al. [2006]: SST) \\
\hline
\end{tabular}

\footnotetext{
${ }^{a}$ Regarding the available chronology of these events in the area (and even if error bars inherent to datings could minimize this remark), cold spells appeared earlier on the northern margin and lasted longer there.
} 
[17] 4. The Younger Dryas (YD) cold event, first described in palynological records from Scandinavia, is known as a true HE in the western North Atlantic (HE0 [e.g., Andrews et al., 1995]). On the European margin, the YD is marked by the installation of subpolar conditions [Baas et al., 1997] and the contraction of temperate tree populations [e.g., Naughton et al., 2007].

[18] 5. The $8.2 \mathrm{ka}$ event is known as a significant temperature anomaly during the early Holocene, which is attributed to a meltwater outflow into the North Atlantic Ocean via the Hudson Strait [Barber et al., 1999; Rohling and Pälike, 2005; Lajeunesse and St-Onge, 2008] that perturbed the overturning circulation [Ellison et al., 2006; Kleiven et al., 2007]. Intrahemispheric impacts of this event were detected in many paleoclimatic records (continental or marine as well [Alley and Ágústsdóttir, 2005]).

\section{Methodology}

[19] The aim of this paper is to track the intrusions of polar waters over the Iberian margin and to delineate the Polar Front. Numerous high-resolution multiproxy records have been generated from sediment cores retrieved through international programs such as ENAM and IMAGES in this area. However, no synoptic synthesis between the different sequences has been carried out, yet. We have selected records adequate to both the existence of comparable proxy data among the cores and to a spatial distribution as wide as possible over the area (Table 1, see also auxiliary material), in order to tentatively draw a synthetic scenario for past sea surface hydrographical changes. ${ }^{1}$

\subsection{Stratigraphical Considerations}

[20] The selected records are high-resolution records mainly from Calypso piston cores retrieved during the IMAGES I (1995) and V (1999) cruises with the R/V Marion Dufresne (IPEV). For ten of the eleven cores used, the age models were previously published (Table 3). The chronostratigraphies were based on calibrated ${ }^{14} \mathrm{C}$ AMS datings and complemented by stratigraphical tie points from a correlation of the stable isotope data with Greenland ice core $\delta^{18} \mathrm{O}$ records (GRIP, GISP2, NorthGRIP). The age model of core MD95-2041 was constructed by a correlation of the planktonic

${ }^{1}$ Auxiliary materials are available at $\mathrm{ftp} / / \mathrm{ftp}$.agu.org/apend/gc/ $2009 \mathrm{gc} 002398$. oxygen isotope curve with those of the nearby sediment cores SU81-18, SO75-26KL, and MD992341 , and with the GISP2 ice core. The lower part of the curve was tied to the stacked oxygen isotope record of Martinson et al. [1987]. For the other cores, we abstained from a further intercore fine tuning of the planktonic oxygen isotope records, and we decided to keep with the published age models, taking into account small stratigraphical discrepancies at certain intervals. These discrepancies were however at an infrascale time resolution than the one we used for our compilation, and therefore do not bias the results presented here. Further details regarding the methodology used to build the age model for each independent core are available in the papers cited in Table 3.

\subsection{Best Proxies to Trace the Polar Front?}

[21] The strategy to select the proxies to compile was motivated by the fact that among the existing set (see Henderson [2002] for a review), some of the most robust and "author to author consistent" paleohydrological proxies are those based on microfossil remains. We therefore focused on data from planktonic foraminifera, which benefit from more than 50 years of paleoceanographic expertise [Kucera, 2007], and which were thoroughly tested through both geochemical (stable isotopes [e.g., Ravelo and Hillaire-Marcel, 2007]) and ecological (transfer function [e.g., Guiot and de Vernal, 2007]) investigations. In particular, we used the planktonic $\delta^{18} \mathrm{O}$ from $G$. bulloides, and the relative abundance of the polar foraminifera $N$. pachyderma sinistral counted in the $>150 \mu \mathrm{m}$ fraction (Figures 3 and 4). The choice to analyze this fraction was justified by the fact, that it has been conventionally adopted for large-scale paleoceanographical reconstructions [e.g., CLIMAP Project Members, 1981; Pflaumann et al., 1996; Kucera et al., 2005b]. Actually, it normally excludes morphologically immature forms (juvenile) and analysis is therefore less subjective. We combined these data with those of large lithic grain (LLG) analyses allowing us to identify ice-rafting activities (referred later in the text as LLG/IRD).

\subsection{Mapping Southward Shifts of the Polar Front Throughout Time}

[22] To support a synoptic view of the migration of the PF throughout time, we created maps reflecting the hydrological conditions over the Iberian margin for the 5 time slices. For mapping, we considered the $\delta^{18} \mathrm{O}$ of $\mathrm{G}$. bulloides together with the relative 


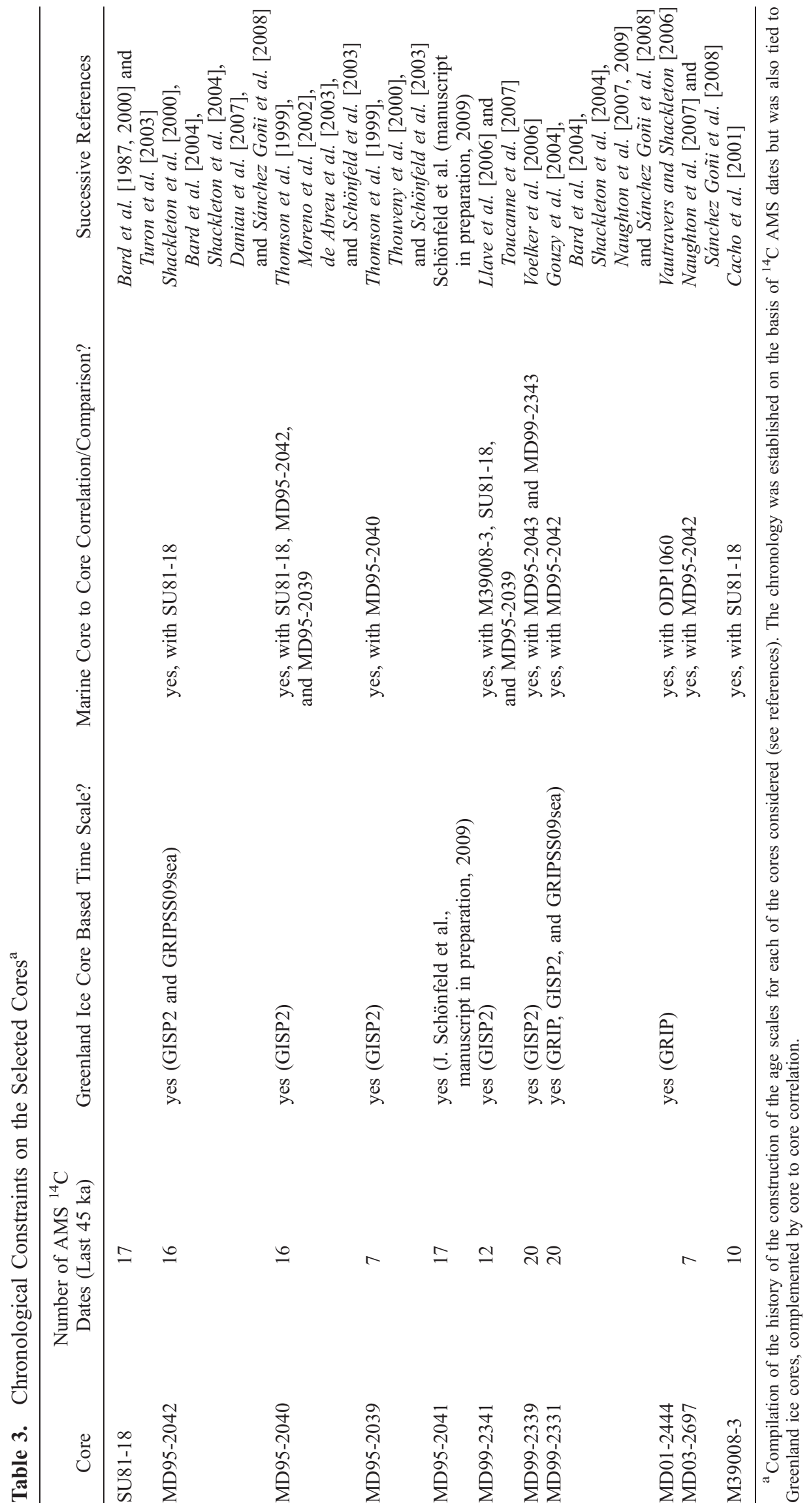




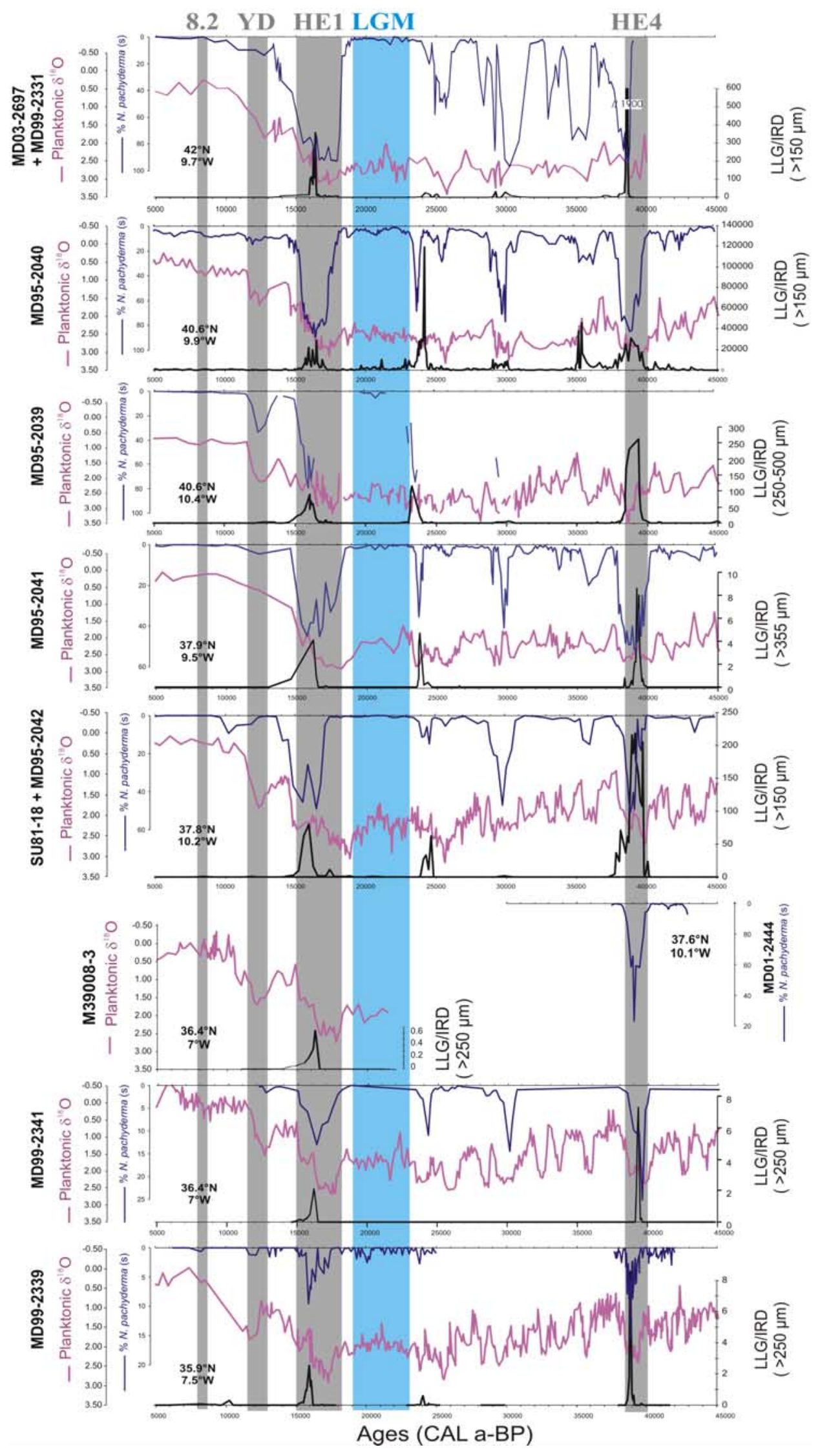

Figure 3 
abundance of $N$. pachyderma sinistral only. The LLG/IRD concentrations were analyzed from different size fractions, in particular $>150 \mu \mathrm{m}$, $>250 \mu \mathrm{m}$, and $>355 \mu \mathrm{m}$, and the values were given as different units, as proportion in the respective grain size fraction or as abundance of lithic grains per gram sediment. The IRD abundance in the $>150 \mu \mathrm{m}$ fraction can be by a factor of 100 higher than those $>250 \mu \mathrm{m}$. Regarding these inconsistencies, we decided not to map the LLG/IRD data, but to use the information to mark ice-rafting periods.

[23] For HE4, HE1, the YD and 8.2 ka events we adopted the approach based on the $\delta^{18} \mathrm{O}$ data developed by Cortijo et al. [2005]; that is, we regarded the difference between planktonic $\delta^{18} \mathrm{O}$ values recorded prior to and during the event itself. During the LGM, however, such changes were not significant. We, therefore, decided to use values averaged over the whole interval. This approach was furthermore justified because of the $4 \mathrm{ka}$ duration of the LGM, and also because previous LGM mapping exercises used mean values over the whole interval as well [CLIMAP Project Members, 1981; Kucera et al., 2005a]. For the $\delta^{18} \mathrm{O}$ mapping we decided to limit our interpretation to the plot of numerical values.

[24] Regarding the $N$. pachyderma sinistral abundances, we decided to plot the maximal abundances recorded for each event (Figure 3) in order to capture the true amplitude of the signal. Our stratigraphical constraint for each of the events is precise enough to exclude diachronism. We interpreted the plots drawing water mass limits with the intention to locate the PF. This was possible only because a good coherency exists between the modern distribution of $N$. pachyderma sinistral in surface sediments and the overlaying surface water masses (see Figure 4). Four major provinces were distinguished that, permit us to consider transitional settings and allow us to better qualify our observations: (1) N. pachyderma sinistral abundances of more than $90 \%$ prevail in the vicinity of the Polar Front, (2) abundances between 50 and 90\% characterize a situation where modified polar water could have reached the margin and generated a front comparable to the present-day Arctic Front,
(3) relative abundances between 50 and 5\% indicated that subarctic waters invaded the area, and (4) relative abundances below 5\% depicted sea surface conditions close to the modern situation.

\section{Polar Front Signature Over the Iberian Margin}

[25] The selected proxies showed a good coherency through time and space, and they permit to distinguish specific events which appear synchronously along the margin. HEs especially exhibit a strong paleohydrological signature, with high $G$. bulloides $\delta^{18} \mathrm{O}$ values and high $N$. pachyderma sinistral percentages, together indicating low SST. The different amplitudes recorded between the cores basically reflect the latitudinal distribution of the records. $N$. pachyderma sinistral occurs for instance, with up to $90 \%$ in quasi-monospecific assemblages at the northern part of the margin whereas its percentages range from 10 to $15 \%$ at maximum in the south (Figure 5). By analogy to the modern distribution of this species in surface sediments of the North Atlantic Ocean (Figure 4), this pattern suggests the penetration of polar surface waters in the north and, at least subpolar surface waters in the south during HEs. LLG/ IRD concentrations also peak during HEs. Even if they were low as compared to those observed within the Ruddiman belt, LLG/IRD concentrations constitute a complementary evidence of the protrusion of polar waters on this margin. Regarding LLG/IRD, HE4 occurs as one of the more drastic events, whereas no lithic was recorded during the YD cold event. The LGM depicts mild sea surface conditions as supported by the near disappearance of $N$. pachyderma sinistral in the fauna. No LLG/IRD pulses were recorded. High G. bulloides $\delta^{18} \mathrm{O}$ values during this interval mirror the change in water $\delta^{18} \mathrm{O}$ related to sea level changes (global ice volume signal), rather than an invasion by cold surface waters [see Waelbroeck et al., 2005]. The $8.2 \mathrm{ka}$ event appears insignificant in the selected records in spite of an accurate resolution of sampling.

Figure 3. Compilation over the last $45 \mathrm{ka}$ of the $\delta^{18} \mathrm{O}$ planktonic records (G. bulloides) used for this work compared, when existing, with the large lithic grain abundances in the sediment (proportion of grains $>150 \mu \mathrm{m}$ or even $>250 \mu \mathrm{m} / \mathrm{g}$ of dried sediment, referred to in the text as LLG/IRD) and with the relative abundances of the polar foraminifera $N$. pachyderma sinistral within the planktonic fossil assemblages $(>150 \mu \mathrm{m})$. From top to bottom, the records are displayed from the northern $\left(42^{\circ} \mathrm{N}\right)$ to the southern one $\left(36^{\circ} \mathrm{N}\right)$. Vertical bars delineate the events we consider for this paper (see also Table 3). For detailed information on the data used, see the auxiliary material. 


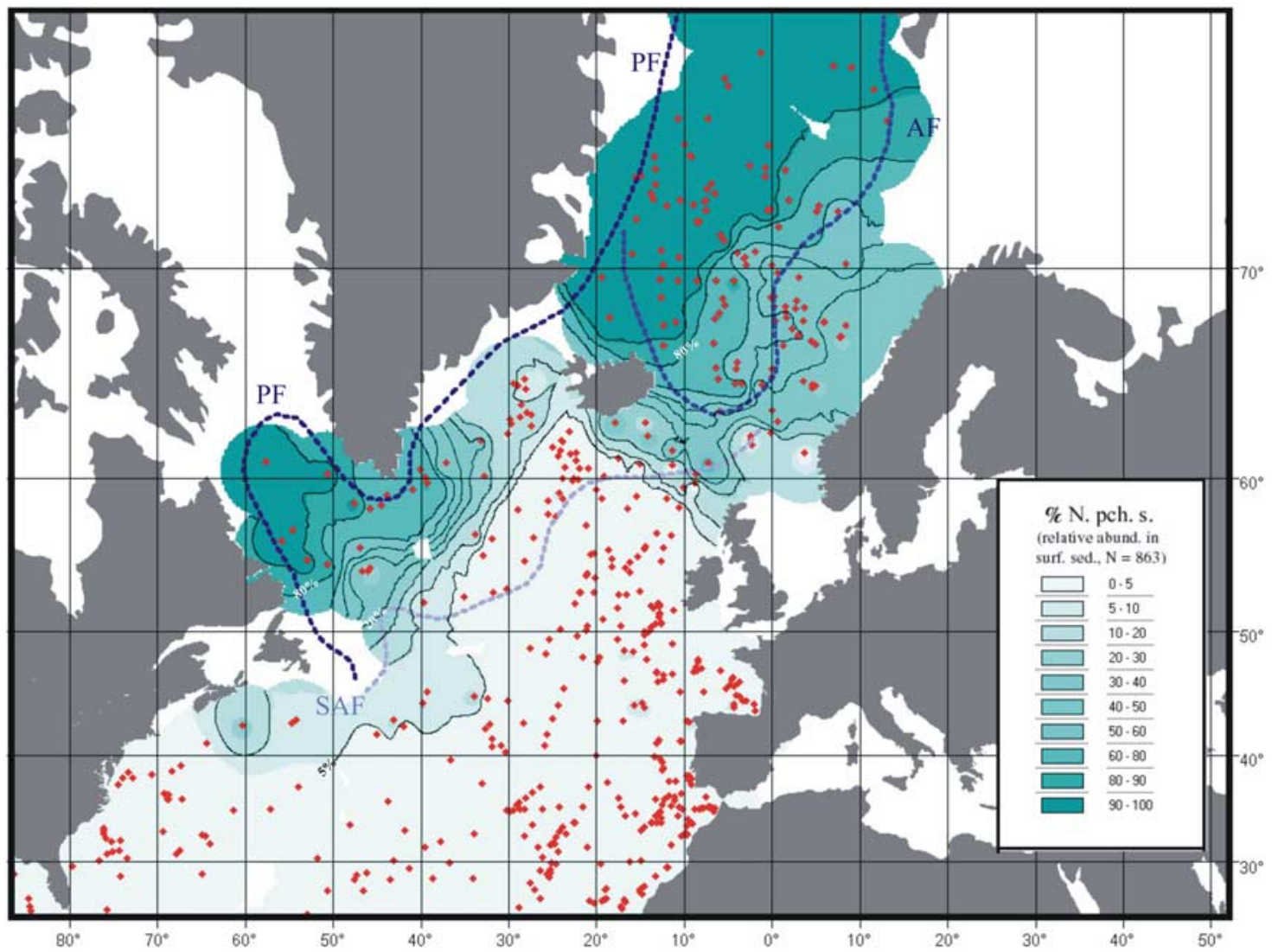

Figure 4. Present-day distribution of the polar foraminifera $N$. pachyderma sinistral in surface sediments of the North Atlantic Ocean (relative abundances mapped with ARCVIEW using the Pflaumann et al. [1996] database). Dotted lines locate the major hydrographic fronts (PF, Polar Front; AF, Arctic Front; SAF, Subarctic Front [after Dickson et al., 1988]).

[26] The 2-D mapping exercise (Figure 5) allows us to constrain the latitudinal range where the $\mathrm{PF}$ could have been positioned. According to our compilation, it becomes clear that the PF reached the area only during HEs. The compilation for HE4 and HE1 produce a very consistent picture, with a PF located close to $42^{\circ} \mathrm{N}$. Arctic and subarctic waters penetrated the area as far south as $36^{\circ} \mathrm{N}$. The cold water may even invaded the western Mediterranean Sea [see Cacho et al., 1999, 2006; Pérez-Folgado et al., 2003; Sierro et al., 2005]. Comparison with the $\delta^{18} \mathrm{O}$ values of $G$. bulloides shows a coherent scheme of heavier values during HE1 and HE4, here showing typical stadial conditions as was demonstrated by Voelker et al. [2006]. However, it is worth noting that the northern margin records display only an attenuate increase of 1.5 to $0.5 \%$. This pattern is in agreement with the proximal position of the northern records to the Ruddiman belt, where a strong depletion in planktonic $\delta^{18} \mathrm{O}$ values due to meltwater influx overprinted the associated signal of low sea surface temperatures (in reverse to the signal directly off Iberia).

[27] The YD also records drastic changes, but the equatorward protrusion of colder water masses seems to have been limited to the installation of subarctic conditions only. This is coherent with the $\delta^{18} \mathrm{O}$ values of $G$. bulloides that increased at that time, but only by 0.5 to $1 \%$ at maximum (Figures 3 and 5).

[28] The LGM and the 8.2 ka event appear to have had only minor impact on the regional SST, with no real distinctive features in the $N$. pachyderma sinistral records. These events display minor changes in the $\delta^{18} \mathrm{O}$ signal of G. bulloides (Figure 5), reaching a maximum of 2.5 to $3 \%$ up to $40^{\circ} \mathrm{N}$ and of 1.5 to $2 \%$ in the southernmost sites during the LGM. Although for some cores, the lower sampling resolution throughout the Holocene seems to contribute to the weak representation of the $8.2 \mathrm{ka}$ 

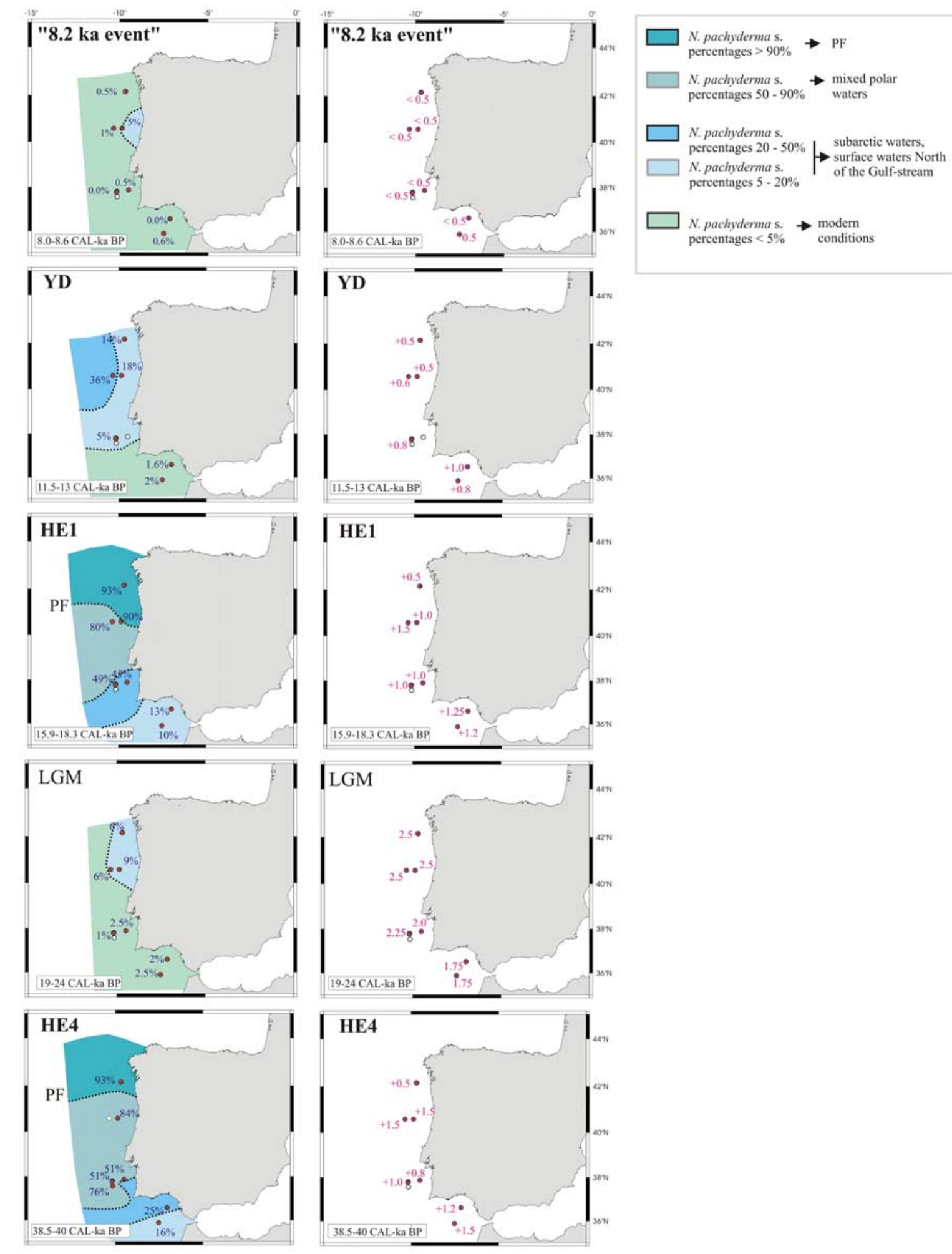

Figure 5. Maps of the selected time snapshots showing potential hydrological indicators of the PF presence along the Iberian margin. (left) Seen by the relative abundance of the polar species $N$. pachyderma sinistral in the sediments (modern values in the area $<5 \%$ ). Delineations in between the different zones have been drawn by interpolation. Note that for HE4, the southern high value of $76 \%$ was recorded for only one level in core MD01-2444. (right) Seen by the amplitude of the calcite $\delta^{18} \mathrm{O}$ of G. bulloides (before the event; during the event, methodology conforms to Cortijo et al. [2005]). For the LGM, we have chosen to indicate the averaged values of G. bulloides $\delta^{18} \mathrm{O}$ over the interval to conform to the Kucera et al. [2005a] project. For detailed information on the data used, see the auxiliary material. 
event, this is not the case for the LGM which furthermore encompasses a 4 ka interval.

\section{Discussion}

\subsection{Impact of HEs Over the Iberian Margin}

[29] Our compilation facilitated schematic views of the hydrological conditions prevailing along the Iberian margin during some cold events of the last $45 \mathrm{ka}$. It shows that the PF incursions were limited to episodes of major ice sheet collapses, i.e., Heinrich events. Further evidence of this drastic impact comes from other independent marine proxies, not compiled here as they were unfortunately not available for all the records considered. Alkenone data similarly revealed major decreases in $\mathrm{SST}$, for instance as large as $5^{\circ} \mathrm{C}$ for HE4 at the southern part of the margin [e.g., Pailler and Bard, 2002; Martrat et al., 2007], and the incursion of less saline waters [Bard et al., 2000]. In the same way, other qualitative studies of plankton related groups, such as dinoflagellate cysts (dinocysts), coccolithophorids or diatoms, also registered major population changes during HEs. Dinocyst assemblages typify the migration of subpolar species over the area, in particular with the occurrence of Bitectatodinium tepikiense or Nematosphaeropis labyrinthus [Eynaud, 1999; Sánchez Goñi et al., 2000; Boessenkool et al., 2001; Turon et al., 2003]. These species are known to be linked to low winter SST and low salinities in subboreal domains today. For coccolithophorids, the small $(6-9 \mu \mathrm{m})$ morphotype of Coccolithus pelagicus s.l. was identified during HEs, in association with $N$. pachyderma sinistral and LLG/IRD peaks [Colmenero-Hidalgo et al., 2004; Parente et al., 2004]. It reveals a shift in the bioprovinces following the invasion of subpolar water masses. At an orbital scale, diatom assemblages and abundances were shown to be linked to oscillations in primary productivity related to the upwelling intensity. Major changes were identified during Terminations and at a lower amplitude during HEs [Abrantes, 1992; Thomson et al., 2000]. This was coherent also with the deposition of a typical lithofacies [Baas et al., 1997], slightly diverging from the lithology of Heinrich layers in the "Ruddiman belt," but in accordance with the more southern position of the Iberian Margin. Benthic communities revealed a drawdown of intermediate and deep-water oxygenation during HEs [Baas et al., 1998; Schönfeld et al., 2003]. These events were furthermore all synchronous with drastic changes on the adjacent Iberian continent, corresponding to the regression of the Mediterranean forest and the development of the steppic vegetation [e.g., Sánchez Goñi et al., 2000; Roucoux et al., 2001, 2005; Combourieu-Nebout et al., 2002; Daniau et al., 2007; Naughton et al., 2007, 2009].

\subsubsection{Upwelling System?}

[30] If convergent data draw the scenario of a sudden installation of extreme environments over the area, we have, however, little evidence of how the local hydrology was affected by HEs. In particular, the dynamic of the local upwelling system is under debate [see also Salgueiro, 2006; Salgueiro et al., 2008]. For instance, the total organic content in sediments off the margin during HEs was interpreted by Pailler and Bard [2002] as indicating a decrease of the upwelling intensity, whereas Lebreiro et al. [1997] suggested the opposite, on the basis of the assumption that high amounts of heavy minerals during HEs result in an artifact in the calculation of organic carbon proportion. This assumption was supported by planktonic foraminiferal data, as high-productivity indexed species were observed in the assemblages during HEs (cores D11957P [Lebreiro et al., 1997] and MD01-2444 [Vautravers and Shackleton, 2006]). The same was demonstrated for dinocysts (core MD95-2042 [Eynaud, 1999; Sánchez Goñi et al., 2000]). Using microcharcoal fluxes to the ocean (core MD95-2042), Daniau et al. [2007] conversely concluded to the prevalence of a southeasterly wind component over the southern Iberian Peninsula and then to a breakdown of the upwelling during HEs and D-O stadials. Their interpretation was coherent with a scenario of a compressed subtropical gyre due to the southward progression of polar water. The Azores High maintained at low latitudes and the prevailing winds from the south could not favor upwelling conditions.

[31] Regarding changes in productivity linked to HEs, Lebreiro et al. [1997] introduced an alternative solution with the idea of a system that was driven by the dynamics around icebergs rather then by the upwelling itself. Following Sancetta [1992], they hypothesized that the presence of drifting ice during HEs, supported high production by turbulent mixing and enhanced density stratification or by the supply of major or trace nutrients. This assumption is still conceivable as enhanced production has recently been observed in the vicinity of free-drifting icebergs in the Weddell Sea [Smith et al., 2007]. It is furthermore highly consistent 
with our mapping, which supports the arrival of possibly nutrient-enriched polar water tongue.

\subsubsection{Regional Currents?}

[32] The shift of the PF and the protrusion of polar waters along the Iberian margin was coupled with a complete reorganization of the surface, intermediate and probably deep circulation in the northeastern Atlantic during HEs. Several surface current patterns around Iberia during HEs or during other cold climate phases in the Northern Hemisphere were proposed [Schönfeld and Zahn, 2000; de Abreu et al., 2003; Rogerson et al., 2004; Vautravers and Shackleton, 2006; Voelker et al., 2006; Llave et al., 2006]. Hypotheses about deep water changes in conjunction with surface water changes through their impact on the overturning circulation have been tested [Schönfeld et al., 2003; Skinner and Elderfield, 2007; Voelker et al., 2006]. These studies support a slowdown or shutoff of the Atlantic meridional overturning circulation (AMOC), coherent with studies from other areas and modeling results [e.g., Roche et al., 2004; Gherardi et al., 2005; Hall et al., 2006]. Synchronously, a drastic change in the Mediterranean Sea circulation happened [Sierro et al., 2005; Voelker et al., 2006]. Indeed, records of MOW paleointensities show that HEs, the YD, and D-O stadials were indeed periods of MOW acceleration [Faugères et al., 1985; Turon and Londeix, 1988; Schönfeld and Zahn, 2000; Cacho et al., 2000; Llave et al., 2006; Voelker et al., 2006; Rogerson et al., 2006; Toucanne et al., 2007].

[33] Our maps are picturing the events as timestatic systems (Figure 5), it is then straightforward to distinguish features representative of a dynamic scheme in surface currents. However, strong thermal gradients during the HEs and the YD support a major sea surface hydrological reorganization in the area. The equatorward protrusion of polar or subpolar waters affected the margin in quite a similar way during the events considered. We can recurrently observe a demarcation at $40^{\circ} \mathrm{N}$ between the northern and southern part of the margin. This latitude has previously been suggested as the southern position of the PF during glacial times [Ruddiman and McIntyre, 1981; Duprat, 1983; Bard et al., 1987]. We demonstrate here that the PF probably oscillated along the northern margin only during HEs around this latitude, but a lens of coastal waters between Lisbon and Cape St Vincent recorded milder conditions at that time. This mirrors the scheme of an upper ocean winter circulation as synthesized by Peliz et al. [2005, see Figure 18, p. 643] with warmer waters on the southern margin linked to a AC-like northward recirculation.

[34] Our maps reveal mean states of the climate episodes that will be useful for model validations. Nonetheless, high-resolution studies have revealed a much more complex pattern of climate/paleoceanographic changes within each individual HE [Bard et al., 2000; Sánchez Goñi et al., 2000, 2002; Voelker et al., 2006; Naughton et al., 2007, 2009, also presented paper, 2007].

\subsection{LGM: Toward a Definitive Revision of CLIMAP Project Members [1981]}

[35] Another important point emerging from our study is that the LGM was not a cold extreme but a period of warming as compared to the surrounding HEs. Following several works, both at the regional scale off the Iberian margin [Eynaud, 1999; Bard et al., 2000; Boessenkool et al., 2001; de Abreu et al., 2003; Turon et al., 2003], as well as at the scale of the North Atlantic Ocean [Sarnthein et al., 1995, 2003; Pflaumann et al., 2003; de Vernal et al., 2000, 2005, 2006], our compilation supports the presence of warm surface water masses between the continent and $10.5^{\circ} \mathrm{W}$ during the LGM. Only the offshore sites off Galicia recorded a slight sea surface cooling at that time (Figure 5). This cooling is, however, of relatively low amplitude, as percentages of the polar taxa $N$. pachyderma sinistral do not exceed $9 \%$. This picture of warm, nearshore waters is coherent with previous studies which have shown the expansion of thermophilous planktonic taxa along the margin (dinocyst [Eynaud, 1999] and foraminifera [de Abreu et al., 2003; Salgueiro, 2006]) and estimated LGM-SST to be cooler by only 1 to $2^{\circ} \mathrm{C}$ relative to present day [de Abreu et al., 2003] or resembling averaged Holocene temperatures [Sánchez Goñi et al., 2008]. Close to the continent, a lens of subtropical waters with SST very similar to the modern ones, seems then to have prevailed, in particular south of $40^{\circ} \mathrm{N}$. This draws the picture of dual subpolar and subtropical-sourced water masses at that time, depending on the latitude, and suggests the penetration of subarctic water masses, but definitely not the installation of the PF on the margin. Instead, we may expect the presence of a strong frontal structure, comparable to the modern Western Iberia Winter Front [Peliz et al., 2005] (Figure 1b). The same evidence of a tongue of warm water was previously related to a "glacial Azores Current" by Parente et al. [2004] and Rogerson et al. [2004]. A 
striking point regarding this "warm" LGM sea surface signature is that the period conversely appears as a cold period on land [e.g., Harrison et al., 2001]. This underlines a decoupling of atmospheric and sea surface processes, probably explained by the large volume and aerial extension of the continental ice at that time over the boreal latitudes, and moreover with a reduced vegetation cover in the vicinity of these large ice sheets. However, some recent demonstration of mitigated situations regarding pollen assemblages have been noted on the Iberian peninsula (Naughton et al., presented paper, 2007).

\subsection{YD and 8.2 ka Events}

[36] The YD experienced much more drastic conditions than the LGM, the later, regarding our mapping, resembling more the "8.2 ka event." The recurrent feature which links these three events, is the partitioning of the margin at $40^{\circ} \mathrm{N}$, with a northern part recording colder conditions. During the YD, penetration of subarctic waters was recognized offshore Galicia with a front splitting the nearshore and offshore sites around $40^{\circ} \mathrm{N}$ that was similar to the modern Western Iberian Winter Front (compare Figures 1 and 5). We can imagine that the milder conditions recorded along the shore, could be linked to a mixture of warmer subtropical waters from $\mathrm{AC}$ recirculations and potentially colder PC or upwelled waters.

\section{Conclusions}

[37] This compilation provides an integrated view of the sea surface conditions that have prevailed during the last $45 \mathrm{ka}$ at the Iberian margin. Focusing on cold extremes of the late Quaternary, we have tentatively drawn schematic maps of sea surface hydrological structures, in order to visualize the migration of the PF. The maps indicated that the PF reached the Iberian margin only during HEs, prevailing in the vicinity of $40^{\circ} \mathrm{N}$. The two selected HEs, HE1 and HE4, were major melting events of the Laurentian and European ice sheets. They left an imprint of very similar amplitudes regarding changes in the sea surface hydrology at the Iberian margin. Our reconstruction constrained the limits of the protrusion of polar surface waters. The maps revealed a partition of the margin into a northern area, where drastic conditions were recorded, and a southern sector where milder conditions prevailed, probably in relation to the influence of the local surface currents (Azores Current notably). The presence of the PF at that time questions the dynamic of the Portuguese upwelling.

[38] Our compilation reveals that the $4 \mathrm{ka}$ time interval of the LGM recorded quite stable sea surface conditions close to the modern ones, at maximum 1 to $2^{\circ} \mathrm{C}$ cooler than today, and thus a low-amplitude cooling when compared to the HEs. More drastic paleoenvironmental changes were recorded during the YD. For the LGM, the YD and also the $8.2 \mathrm{ka}$ event, the northern margin experienced the most pronounced cooling, inferring further evidence for a different response of the northern and southern Iberian margin.

\section{Acknowledgments}

[39] The authors would like to thank all the participants of the respective scientific cruises (IMAGES I, GEOSCIENCES, GINNA- IMAGES V, and PICABIA) along with the captains and the crews of the R/V Marion Dufresne, supported by the following French agencies: Ministère de l'Education Nationale de la Recherche et de la Technologie (MENRT), Centre National de la Recherche Scientifique (CNRS), and Institut Paul Emile Victor (IPEV). F.E. acknowledges financial support from the French contract of the ANR IDEGLACE and the ESF RESOLUTION project. L.A., E.S., and A.V. received financial support by the Portuguese Foundation for Science and Technology. J.S. acknowledges funding by the European Commission's Framework Six Programme (HERMES project, contract GOCE-CT-2005-511234-1). Comments by the reviewers, including Alessandra Asioli, significantly benefited this paper. This is UMR/EPOC CNRS 5805 contribution 1745 .

\section{References}

Abrantes, F. (1992), Palaeoproductivity oscillations during the last $130 \mathrm{ka}$ along the Portuguese and NW African margins, in The Geological Record of Upwelling Evolution, Geol. Soc. Spec. Publ., 64, 499-510.

Abrantes, F., J. Baas, H. Haflidason, T. Rasmussen, D. Klitgaard, N. Loncaric, and L. Gaspar (1998), Sediment fluxes along the northeastern European Margin: Inferring hydrological changes between 20 and 8 kyr, Mar. Geol., 152, 7-23, doi:10.1016/ S0025-3227(98)00062-0.

Alley, R. B., and A. M. Ágústsdóttir (2005), The 8k event: Cause and consequences of a major Holocene abrupt climate change, Quat. Sci. Rev., 24(10-11), 1123-1149, doi:10.1016/j.quascirev.2004.12.004.

Ambar, I., and M. Howe (1979), Observations of the Mediterranean Outflow-I. Mixing in the Mediterranean Outflow, Deep Sea Res., Part A, 26, 535-554, doi:10.1016/01980149(79)90095-5.

Andrews, J. T., A. E. Jennings, M. Kerwin, M. E. Kirby, W. Manley, G. H. Miller, G. Bond, and B. MacLean (1995), A Heinrich-like event, H-0(DC-0), Source(s) for detrital carbonate in the North Atlantic during the Younger Dryas chronozone, Paleoceanography, 10, 943-952, doi:10.1029/95PA01426. 
Baas, J. H., J. Mienert, F. Abrantes, and M. A. Prins (1997), Late Quaternary sedimentation on the Portuguese continental margin: Climate related processes and products, Palaeogeogr. Palaeoclimatol. Palaeoecol., 130, 1-23, doi:10.1016/S0031-0182(96)00135-6.

Baas, J. H., J. Schönfeld, and R. Zahn (1998), Mid-depth oxygen drawdown during Heinrich events: Evidence from benthic foraminiferal community structure, trace-fossil tiering, and benthic $\delta^{13} \mathrm{C}$ at the Portuguese Margin, Mar. Geol., 152, 25-55, doi:10.1016/S0025-3227(98)00063-2.

Barber, D. C., et al. (1999), Forcing of the cold event of 8,200 years ago by catastrophic drainage of Laurentide lakes, Nature, 400, 344-348, doi:10.1038/22504.

Bard, E. (1998), Geochemical and geophysical implications of the radiocarbon calibration, Geochim. Cosmochim. Acta, 62, 2025-2038, doi:10.1016/S0016-7037(98)00130-6.

Bard, E., M. Arnold, P. Maurice, J. Duprat, J. Moyes, and J. C. Duplessy (1987), Retreat velocity of the North Atlantic polar front during the last deglaciation determined by ${ }^{14} \mathrm{C}$ accelerator mass spectrometry, Nature, 328, 791794, doi:10.1038/328791a0.

Bard, E., F. Rostek, J.-L. Turon, and S. Gendreau (2000), Hydrological impact of Heinrich events in the subtropical northeast Atlantic, Science, 289, 1321-1324, doi:10.1126/ science.289.5483.1321.

Bard, E., F. Rostek, and G. Ménot-Combes (2004), Radiocarbon calibration beyond $20,000{ }^{14} \mathrm{C}$ yr B.P. by means of planktonic foraminifera of the Iberian Margin, Quat. Res., 61, 204-241, doi:10.1016/j.yqres.2003.11.006.

Boessenkool, K. P., H. Brinkhuis, J. Schönfeld, and J. Targarona (2001), North Atlantic sea-surface temperature changes and the climate of western Iberia during the last deglaciation; a marine palynological approach, Global Planet. Change, 30, 33-39, doi:10.1016/S0921-8181(01)00075-3.

Bond, G., W. Broecker, S. Johnsen, J. McManus, L. Labeyrie, G. Jouzel, and G. Bonani (1993), Correlations between climate records from North Atlantic sediments and Greenland ice, Nature, 365, 143-147, doi:10.1038/365143a0.

Byrkjedal, Ø., N. G. Kvamstø, M. Meland, and E. Jansen (2006), Sensitivity of last glacial maximum climate to sea ice conditions in the Nordic Seas, Clim. Dyn., 26, 473-487, doi:10.1007/s00382-005-0096-2.

Cacho, I., J. O. Grimalt, C. Pelejero, M. Canals, F. J. Sierro, J. A. Flores, and N. J. Shackleton (1999), Dansgaard-Oeschger and Heinrich events imprints in Alboran Sea paleotemperatures, Paleoceanography, 14, 698-705, doi:10.1029/ 1999PA900044.

Cacho, I., J. O. Grimalt, F. J. Sierro, N. J. Shackleton, and M. Canals (2000), Evidence for enhanced Mediterranean thermohaline circulation during rapid climatic coolings, Earth Planet. Sci. Lett., 183(3-4), 417-429, doi:10.1016/ S0012-821X(00)00296-X.

Cacho, I., J. O. Grimalt, M. Canals, L. Sbaffi, N. J. Shackleton, J. Schönfeld, and R. Zahn (2001), Variability of the western Mediterranean Sea surface temperature during the last 25,000 years and its connection with the Northern Hemisphere climatic changes, Paleoceanography, 16, 40-52, doi:10.1029/2000PA000502.

Cacho, I., N. Shackleton, H. Elderfield, F. J. Sierro, and J. O. Grimalt (2006), Glacial rapid variability in deep-water temperature and $\delta^{18} \mathrm{O}$ from the western Mediterranean Sea, Quat. Sci. Rev., 25, 3294-3311, doi:10.1016/j.quascirev. 2006.10.004

Calvo, E., J. Villanueva, J. O. Grimalt, A. Boelaert, and L. Labeyrie (2001), New insights into the glacial latitudinal temperature gradients in the North Atlantic. Results from
Uk37' sea surface temperatures and terrigenous inputs, Earth Planet. Sci. Lett., 188, 509-519, doi:10.1016/S0012821X(01)00316-8.

CLIMAP Project Members (1981), Seasonal reconstructions of the Earth's surface at the last glacial maximum, Map and Chart Ser., vol. 36, 18 pp., Geol. Soc. of Am., Boulder, Colo.

Colmenero-Hidalgo, E., J. A. Flores, F. J. Sierro, M. A. Bárcena, L. Löwemark, J. Schönfeld, and J. O. Grimalt (2004), Ocean surface water response to short-term climate changes revealed by coccolithophores from the Gulf of Cadiz (NE Atlantic) and Alboran Sea (W Mediterranean), Palaeogeogr. Palaeoclimatol. Palaeoecol., 205, 317-336, doi:10.1016/j.palaeo. 2003.12.014.

Combourieu-Nebout, N., J. L. Turon, R. Zahn, L. Capotondi, L. Londeix, and K. Pahnke (2002), Enhanced aridity and atmospheric high-pressure stability over the western Mediterranean during the North Atlantic cold events of the past 50 k.y., Geology, 30, 863-866, doi:10.1130/00917613(2002)030<0863:EAAAHP>2.0.CO;2.

Cortijo, E., L. Labeyrie, L. Vidal, M. Vautravers, M. Chapman, J. C. Duplessy, M. Elliot, M. Arnold, J. L. Turon, and G. A. Auffret (1997), Changes in sea surface hydrology associated with Heinrich event 4 in the North Atlantic Ocean between $40^{\circ}$ and $60^{\circ} \mathrm{N}$, Earth Planet. Sci. Lett., 146, 29-45, doi:10.1016/S0012-821X(96)00217-8.

Cortijo, E., J. Duplessy, L. Labeyrie, J. Duprat, and D. Paillard (2005), Heinrich events: Hydrological impact, C. R. Geosci., 337(10-11), 897-907, doi:10.1016/j.crte.2005.04.011.

Crowley, T. (1981), Temperature and circulation changes in the eastern north Atlantic during the last 150,000 years: Evidence from the planktonic foraminiferal record, Mar. Micropaleontol., 6, 97-129, doi:10.1016/0377-8398(81)90001-3.

Curry, W. B., T. M. Marchitto, J. F. McManus, D. W. Oppo, and K. L. Laarkamp (1999), Millennial-scale changes in ventilation of the thermocline, intermediate, and deep waters of the Glacial North Atlantic, in Mechanisms of Global Climate Change at Millennial Time Scales, Geophys. Monogr. Ser, vol. 112, edited by P. U. Clark, R. S. Webb, and L. D. Keigwin, pp. 59-76, AGU, Washington, D. C.

Daniau, A.-L., M. F. Sánchez-Goñi, L. Beaufort, F. LaggounDéfarge, M.-F. Loutre, and J. Duprat (2007), DansgaardOeschger climatic variability revealed by fire emissions in southwestern Iberia, Quat. Sci. Rev., 26, 1369-1383, doi:10.1016/j.quascirev.2007.02.005.

Dansgaard, W., et al. (1993), Evidence for general instability of past climate from 250-kyr ice-core record, Nature, 364, 218-220, doi:10.1038/364218a0.

de Abreu, L., N. J. Shackleton, J. Schönfeld, M. Hall, and M. Chapman (2003), Millennial-scale oceanic climate variability off the western Iberian margin during the last two glacial periods, Mar. Geol., 196, 1-20, doi:10.1016/S0025-3227 (03)00046-X.

de Vernal, A., C. Hillaire-Marcel, J.-L. Turon, and J. Matthiessen (2000), Reconstruction of sea-surface temperature, salinity, and sea-ice cover in the northern North Atlantic during the last glacial maximum based on dinocyst assemblages, Can. J. Earth Sci., 37, 725-750, doi:10.1139/cjes-37-5-725.

de Vernal, A., et al. (2005), Reconstruction of sea-surface conditions at middle to high latitudes of the Northern Hemisphere during the last glacial maximum (LGM) based on dinoflagellate cyst assemblages, Quat. Sci. Rev., 24, 897924, doi:10.1016/j.quascirev.2004.06.014.

de Vernal, A., A. Rosell-Melé, M. Kucera, C. Hillaire-Marcel, F. Eynaud, M. Weinelt, T. Dokken, and M. Kageyama 
(2006), Multiproxy reconstruction of LGM sea-surface conditions in the northern North Atlantic, Quat. Sci. Rev., 25, 2820-2834, doi:10.1016/j.quascirev.2006.06.006.

Dickson, R. R., J. Meincke, S.-A. Malmberg, and A. J. Lee (1988), The "great salinity anomaly" in the northern North Atlantic 1968-1982, Prog. Oceanogr., 20, 103-151, doi:10.1016/0079-6611(88)90049-3.

Dowdeswell, J. A., M. A. Maslin, J. T. Andrews, and I. N. McCave (1995), Iceberg production, debris rafting, and the extent and thickness of Heinrich layers $(\mathrm{H}-1, \mathrm{H}-2)$ in North Atlantic sediments, Geology, 23, 301-304, doi:10.1130/ 0091-7613(1995)023<0297:IPDRAT>2.3.CO;2.

Duprat, J. (1983), Les foraminifères planctoniques du Quaternaire terminal d'un domaine péricontinental (Golfe de Gascogne, Cote Ouest Ibérique, Mer d'Alboran): EcologieBiostratigraphie, 3rd cycle thesis, 177 pp., Univ. Bordeaux 1, Talence, France.

Elliot, M., L. Labeyrie, G. Bond, E. Cortijo, J.-L. Turon, N. Tisnerat, and J.-C. Duplessy (1998), Millennial-scale iceberg discharges in the Irminger Basin during the last glacial period: Relationship with the Heinrich events and environmental settings, Paleoceanography, 13(5), 433-446, doi:10.1029/98PA01792.

Elliot, M., L. Labeyrie, and J. C. Duplessy (2002), Changes in North Atlantic deep-water formation associated with the Dansgaard-Oeschger temperature oscillations (60-10 ka), Quat. Sci. Rev., 21, 1153-1165.

Elliot, M., L. Labeyrie, T. Dokken, and S. Manthe (2001), Coherent patterns of ice-rafted debris deposits in the Nordic regions during the last glacial $(10-60 \mathrm{Ka})$, Earth Planet. Sci. Lett., 194, 151-163.

Ellison, C. R. W., M. R. Chapman, and I. R. Hall (2006), Surface and deep ocean interactions during the cold climate event 8200 years ago, Science, 312, 1929-1932, doi:10.1126/science.1127213.

Eynaud, F. (1999), Kystes de Dinoflagellés et Evolution paléoclimatique et paléohydrologique de l'Atlantique Nord au cours du Dernier Cycle Climatique du Quaternaire, Ph.D. thesis, 291 pp., Univ. Bordeaux 1, Talence, France.

Eynaud, F., J. L. Turon, M.-F. Sánchez-Goñi, and S. Gendreau (2000), Dinoflagellate cyst evidence of 'Heinrich-like events' off Portugal during the Marine Isotopic Stage 5, Mar. Micropaleontol., 40, 9-21, doi:10.1016/S03778398(99)00045-6.

Faugères, J. C., M. Frappa, E. Gonthier, and F. Grousset (1985), Impact de la veine d'eua méditerranéenne sur la sédimentation de la marge Sud et Ouest ibérique au Quaternaire récent, Bull. Inst. Geol. Bassin Aquitaine, 37, 259287.

Fiúza, A. F. G. (1984), Hidrologia e dinâmica das águas costeiras de Portugal, Ph.D. thesis, Univ. of Lisbon, Lisbon.

Fiúza, A., M. Macedo, and M. Guerreiro (1982), Climatological space and time variation of the Portuguese coastal upwelling, Oceanol. Acta, 5, 31-40.

Fiúza, A. F. G., M. Hamann, I. Ambar, G. D. Del Rio, N. González, and J. M. Cabanas (1998), Water masses and their circulation off western Iberia during May 1993, Deep Sea Res., Part I, 45, 1127-1160, doi:10.1016/S0967-0637 (98)00008-9.

Garcia-Soto, C., R. D. Pingree, and L. Valdés (2002), Navidad development in the southern Bay of Biscay: Climate change and swoddy structure from remote sensing and in situ measurements, J. Geophys. Res., 107(C8), 3118, doi:10.1029/ 2001JC001012.

Gherardi, J. M., L. Labeyrie, J. F. McManus, R. Francois, L. C. Skinner, and E. Cortijo (2005), Evidence from the northeast- ern Atlantic basin for variability in the rate of the meridional overturning circulation through the last deglaciation, Earth Planet. Sci. Lett., 240, 710-723, doi:10.1016/j.eps1. 2005.09.061.

Gouzy, A., B. Malaizé, C. Pujol, and K. Charlier (2004), Climatic "pause" during Termination II identified in shallow and intermediate waters off the Iberian margin, Quat. Sci. Rev., 23, 1523-1528, doi:10.1016/j.quascirev.2004.03.002.

Grousset, F. E., L. D. Labeyrie, J. A. Sinko, M. Cremer, G. Bond, J. Duprat, E. Cortijo, and S. Huon (1993), Patterns of ice-rafted detritus in the glacial North Atlantic $\left(40^{\circ}-55^{\circ} \mathrm{N}\right)$, Paleoceanography, 8, 175-192, doi:10.1029/92PA02923.

Grousset, F., C. Pujol, L. Labeyrie, G. A. Auffret, and A. Boelaert (2000), Were the North Atlantic Heinrich events triggered by the behaviour of the European ice sheet?, Geology, 28, 123-126, doi:10.1130/0091-7613(2000)28<123: WTNAHE $>2.0 . \mathrm{CO} ; 2$.

Guiot, J., and A. de Vernal (2007), Transfer functions: Methods for quantitative paleoceanography based on microfossils, in Developments in Marine Geology, vol. 1, Proxies in Late Cenozoic Paleoceanography, edited by C. Hillaire-Marcel and A. de Vernal, pp. 523-563, Elsevier, New York.

Hall, I. R., S. B. Moran, R. Zahn, P. C. Knutz, C.-C. Shen, and R. L. Edwards (2006), Accelerated drawdown of meridional overturning in the late-glacial Atlantic triggered by transient pre-H event freshwater perturbation, Geophys. Res. Lett., 33, L16616, doi:10.1029/2006GL026239.

Harrison, S. P., and C. I. Prentice (2003), Climate and $\mathrm{CO}_{2}$ controls on global vegetation distribution at the last glacial maximum: Analysis based on palaeovegetation data, biome modelling and palaeoclimate simulations, Global Change Biol., 9(7), 983-1004, doi:10.1046/j.1365-2486.2003. 00640.x.

Harrison, S. P., K. E. Kohfeld, C. Roelandt, and T. Claquin (2001), The role of dust in climate changes today, at the last glacial maximum and in the future, Earth Sci. Rev., 54(1-3), 43-80, doi:10.1016/S0012-8252(01)00041-1.

Haynes, R., and E. D. Barton (1990), A poleward flow along the Atlantic coast of the Iberian Peninsula, J. Geophys. Res., 95, 11,425-11,441, doi:10.1029/JC095iC07p11425.

Heinrich, H. (1988), Origin and consequences of cyclic ice rafting in the northeast Atlantic Ocean during the past 130,000 years, Quat. Res., 29, 142-152, doi:10.1016/00335894(88)90057-9.

Hemming, S. R. (2004), Heinrich events: Massive late Pleistocene detritus layers of the North Atlantic and their global climate imprint, Rev. Geophys., 42, RG1005, doi:10.1029/ 2003RG000128.

Hemming, S. R., W. S. Broecker, W. D. Sharp, G. C. Bond, R. H. Gwiazda, J. F. McManus, M. Klas, and I. Hajdas (1998), Provenance of Heinrich layers in core V28-82, northeastern Atlantic: ${ }^{40} \mathrm{Ar} /{ }^{39} \mathrm{Ar}$ ages of ice-rafted hornblende, $\mathrm{Pb}$ isotopes in feldspar grains, and $\mathrm{Nd}-\mathrm{Sr}-\mathrm{Pb}$ isotopes in the fine sediment fraction, Earth Planet. Sci. Lett., 164, 317-333.

Henderson, G. M. (2002), New oceanic proxies for paleoclimate, Earth Planet. Sci. Lett., 203, 1-13, doi:10.1016/ S0012-821X(02)00809-9.

Holliday, N. P., A. Meyer, S. Bacon, S. G. Alderson, and B. de Cuevas (2007), Retroflection of part of the east Greenland current at Cape Farewell, Geophys. Res. Lett., 34, L07609, doi:10.1029/2006GL029085.

Iorga, M. C., and S. Lozier (1999), Signature of the Mediterranean outflow from a North Atlantic climatology: 1. Salinity and density field, J. Geophys. Res., 104(C11), 25,98526,009, doi:10.1029/1999JC900115. 
Jia, Y. (2000), Formation of an Azores Current due to Mediterranean overflow in a modelling study of the North Atlantic, J. Phys. Oceanogr., 30, 2342-2358, doi:10.1175/ 1520-0485(2000)030<2342:FOAACD $>2.0 . C O ; 2$.

Kleiven, H. F., C. Kissel, C. Laj, U. S. Ninnemann, T. O. Richter, and E. Cortijo (2007), Reduced North Atlantic Deep Water coeval with the glacial Lake Agassiz freshwater outburst, Science, 319, 60-64, doi:10.1126/science.1148924.

Kucera, M. A. (2007), Planktonic foraminifera as tracers of past oceanic environments, in Developments in Marine Geology, vol. 1, Proxies in Late Cenozoic Paleoceanography, edited by C. Hillaire-Marcel and A. de Vernal, pp. 213-262, Elsevier, New York.

Kucera, M., , R. Schneider, and M. Weinelt (Eds.) (2005a), Multiproxy Approach for the Reconstruction of the Glacial Ocean surface, Quat. Sci. Rev., 24, 306 pp.

Kucera, M., A. Rosell-Melé, R. Schneider, C. Waelbroeck, and M. Weinelt (2005b), Multiproxy approach for the reconstruction of the glacial ocean surface (MARGO), Quat. Sci. Rev., 24, 813-819, doi:10.1016/j.quascirev.2004.07.017.

Kudrass, H. R. (1973), Sedimentation am Kontinentalhang vor Portugal und Marokko im Spätpleistozän und Holozän, Meteor Forschungsergeb. Reihe C, 13, 1-63.

Lajeunesse, P., and G. St-Onge (2008), Subglacial origin of Lake Agassiz-Ojibway final outburst flood, Nat. Geosci., 1, 184-188, doi:10.1038/ngeo130.

Lebreiro, S. M., J. C. Moreno, I. N. McCave, and P. P. E. Weaver (1996), Evidence for Heinrich layers off Portugal (Tore Seamount: $39^{\circ} \mathrm{N}, 12^{\circ} \mathrm{W}$ ), Mar. Geol., 131, 47-56, doi:10.1016/0025-3227(95)00142-5.

Lebreiro, S. M., J. C. Moreno, F. F. Abrantes, and U. Pflaumann (1997), Productivity on the Tore Seamount (Iberian Margin) during the last 225 kyr: Foraminiferal evidence, Paleoceanography, 12, 718-727, doi:10.1029/97PA01748.

Leuschner, D. C., and F. Sirocko (2000), The low-latitude monsoon climate during Dansgaard-Oeschger cycles and Heinrich events, Quat. Sci. Rev., 19, 243-254, doi:10.1016/S0277-3791(99)00064-5.

Levitus, S. (1994), World Ocean Atlas 1994, http:// www.cdc.noaa.gov/data/gridded/data.nodc.woa94.html, Natl. Oceanogr. Data Cent., NOAA, Silver Spring, Md.

Lisiecki, L. E., M. E. Raymo, and W. B. Curry (2008), Atlantic overturning responses to Late Pleistocene climate forcings, Nature, 456, 85-88, doi:10.1038/nature07425.

Llave, E., J. Schönfeld, F. J. Hernandez-Molina, T. Mulder, L. Somoza, V. Diaz del Rio, and I. Sanchez-Almazo (2006), High-resolution stratigraphy of the Mediterranean outflow contourite system in the Gulf of Cadiz during the late Pleistocene: The impact of Heinrich events, Mar. Geol., 227(3-4), 241-262, doi:10.1016/j.margeo.2005.11.015.

Martinson, D. G., N. G. Pisias, J. D. Hays, J. Imbrie, T. C. More, Jr., and N. J. Shackleton (1987), Age dating and the orbital theory of the ice ages: Development of a high-resolution 0 to 300,000-year chronostratigraphy, Quat. Res., 27, 1-29, doi:10.1016/0033-5894(87)90046-9.

Martrat, B., J. O. Grimalt, C. Lopez-Martinez, I. Cacho, F. J. Sierro, J. A. Flores, R. Zahn, M. Canals, J. H. Curtis, and D. A. Hodell (2004), Abrupt temperature changes in the western Mediterranean over the past 250,000 years, Science, 306, 1762-1765, doi:10.1126/science. 1101706

Martrat, B., J. O. Grimalt, N. J. Shackleton, L. de Abreu, M. A. Hutterli, and T. F. Stocker (2007), Four climate cycles of recurring deep and surface water destabilizations on the Iberian Margin, Science, 317, 502-507, doi:10.1126/ science.1139994.
Maslin, M. A., N. J. Shackleton, and U. Pflaumann (1995), Surface water temperature, salinity and density changes in the northeast Atlantic during the last 45,000 years: Heinrich events, deep-water formation and climate rebounds, Paleoceanography, 10(3), 527-544, doi:10.1029/94PA03040.

McIntyre, A., N. G. Kipp, A. W. H. Be, T. Crowley, T. Kellogg, J. V. Gardner, W. Prell, and W. F. Ruddiman (1976), Glacial North Atlantic years ago: A CLIMAP reconstruction, in Investigation of Late Quaternary Paleoceanography and Paleoclimatology, edited by R. M. Cline and J. D. Hays, Mem. Geol. Soc. Am., 145, 43-76.

Mix, A. E., E. Bard, and R. Schneider (2001), Environmental processes of the ice age: Land, ocean, glaciers (EPILOG), Quat. Sci. Rev., 20, 627-657, doi:10.1016/S02773791(00)00145-1.

Moreno, E., N. Thouveny, D. Delanghe, I. N. McCave, and N. J. Shackleton (2002), Climatic and oceanographic changes in the northeast Atlantic reflected by magnetic properties of sediments deposited on the Portuguese margin during the last $340 \mathrm{ka}$, Earth Planet. Sci. Lett., 202, 465-480, doi:10.1016/S0012-821X(02)00787-2.

Narciso, A., M. Cachão, and L. de Abreu (2006), Coccolithus pelagicus subsp. pelagicus versus Coccolithus pelagicus subsp. braarudii (Coccolithophore, Haptophyta): A proxy for surface subarctic Atlantic waters off Iberia during the last 200 kyr, Mar. Micropaleontol., 59, 15-34, doi:10.1016/ j.marmicro.2005.12.001.

Naughton, F., M. F. Sánchez Goñi, S. Desprat, J.-L. Turon, J. Duprat, B. Malaizé, C. Joli, E. Cortijo, T. Drago, and M. C. Freitas (2007), Present-day and past (last 25,000 years) marine pollen signal off western Iberia, Mar. Micropaleontol., 62, 91-114, doi:10.1016/j.marmicro.2006.07.006.

Naughton, F., M. F. Sánchez Goñi, M. Kageyama, E. Bard, J. Duprat, E. Cortijo, S. Desprat, B. Malaizé, C. Joly, and F. Rostek (2009), Wet to dry climatic trend in north western Iberia within Heinrich events, Earth Planet. Sci. Lett., in press.

Pailler, D., and E. Bard (2002), High frequency palaeoceanographic changes during the past 140,000 yr recorded by the organic matter in sediments of the Iberian margin, Palaeogeogr. Palaeoclimatol. Palaeoecol., 181, 431-452, doi:10.1016/S0031-0182(01)00444-8.

Parente, A., M. Cachão, K.-H. Baumman, L. de Abreu, and J. Ferreira (2004), Morphometry of Coccolithus pelagicus s.l. (Coccolithophore, Haptophyta) from offshore Portugal, during the last 200 kyrs, Micropaleontology, 50, 107-120, doi:10.2113/50.Suppl_1.107.

Peck, V. L., I. R. Hall, R. Zahn, F. Grousset, S. R. Hemming, and J. D. Scourse (2007), The relationship of Heinrich events and their European precursors over the past $60 \mathrm{ka} \mathrm{BP}$ : A multi-proxy ice-rafted debris provenance study in the north east Atlantic, Quat. Sci. Rev., 26(7-8), 862-875, doi:10.1016/j.quascirev.2006.12.002.

Peliz, A., J. Dubert, A. Santos, P. Oliveira, and B. Le Cann (2005), Winter upper ocean circulation in the Western Iberian Basin-Fronts, eddies and poleward flows: An overview, Deep Sea Res., Part I, 52, 621-646, doi:10.1016/ j.dsr.2004.11.005.

Pérez-Folgado, M., F. J. Sierro, J. A. Flores, I. Cacho, J. O. Grimalt, R. Zahn, and N. Shackleton (2003), Western Mediterranean planktonic foraminifera events and millennial climatic variability during the last $70 \mathrm{kyr}$, Mar. Micropaleontol., 48, 49-70, doi:10.1016/S0377-8398(02)00160-3.

Pflaumann, U., J. Duprat, C. Pujol, and L. Labeyrie (1996), SIMMAX: A modern analog technique to deduce Atlantic 
sea surface temperatures from planktonic foraminifera in deep-sea sediments, Paleoceanography, 11, 15-35, doi:10.1029/95PA01743.

Pflaumann, U., et al. (2003), Glacial North Atlantic: Sea-surface conditions reconstructed by GLAMAP 2000, Paleoceanography, 18(3), 1065, doi:10.1029/2002PA000774.

Ravelo, C., and C. Hillaire-Marcel (2007), The use of oxygen and carbon isotopes of foraminifera in paleoceanography, in Developments in Marine Geology, vol. 1, Proxies in Late Cenozoic Paleoceanography, edited by C. Hillaire-Marcel and A. de Vernal, pp. 735-764, Elsevier, New York.

Relvas, P., A. Peliz, E. D. Barton, J. C. da Silva, J. Dubert, M. Santos, and P. B. Oliveira (2007), Western Iberia Upwelling Ecosystem: An oceanographic overview, Prog. Oceanogr., 74, 149-173, doi:10.1016/j.pocean.2007.04.021.

Roche, D., D. Paillard, and E. Cortijo (2004), Constraints on the duration and freshwater release of Heinrich event 4 through isotope modelling, Nature, 432, 379-382, doi:10.1038/nature03059.

Rogerson, M., E. J. Rohling, P. P. E. Weaver, and J. W. Murray (2004), The Azores Front since the Last Glacial Maximum, Earth Planet. Sci. Lett., 222, 779-789, doi:10.1016/ j.eps1.2004.03.039.

Rogerson, M., E. J. Rohling, and P. P. E. Weaver (2006), Promotion of meridional overturning by Mediterranean-derived salt during the last deglaciation, Paleoceanography, 21, PA4101, doi:10.1029/2006PA001306.

Rohling, E. J., and H. Pälike (2005), Centennial-scale climate cooling with a sudden cold event around 8,200 years ago, Nature, 434, 975-979, doi:10.1038/nature03421.

Roucoux, K., N. J. Shackleton, L. de Abreu, J. Schönfeld, and P. C. Tzedakis (2001), Combined marine proxy and pollen analyses reveal rapid vegetation response to North Atlantic millennial-scale climate oscillations, Quat. Res., 56(1), $128-$ 132, doi:10.1006/qres.2001.2218.

Roucoux, K. H., P. C. Tzedakis, L. de Abreu, and N. J. Shackleton (2005), The response of NW Iberian vegetation to North Atlantic climate oscillations during the last 65,000 years, Quat. Sci. Rev., 24, 1637-1653, doi:10.1016/j.quascirev. 2004.08.022.

Ruddiman, W. F. (1977), Late Quaternary deposition of icerafted sand in the sub-polar North Atlantic (lat. $40^{\circ}$ to $65^{\circ}$ ), Geol. Soc. Am. Bull., 88, 1813-1821, doi:10.1130/00167606(1977)88<1813:LQDOIS >2.0.CO;2.

Ruddiman, W. F., and A. McIntyre (1981), The North Atlantic Ocean during the last deglaciation, Palaeogeogr. Palaeoclimatol. Palaeoecol., 35, 145-214, doi:10.1016/0031-0182(81) 90097-3.

Salgueiro, E., et al. (2008), Planktonic foraminifera from modern sediments reflect upwelling patterns off Iberia: Insights from a regional transfer function, Mar. Micropaleontol., 66, 135-164, doi:10.1016/j.marmicro.2007.09.003.

Salgueiro, M. E. C. (2006), Oceanography and productivity conditions on the Iberian margin: A $150 \mathrm{ky}$ foraminifera record, Ph.D. thesis, Univ. Bremen, Bremen, Germany. (Available at http://elib.suub.uni-bremen.de/diss/docs/ 00010538.pdf)

Sancetta, C. (1992), Primary production in the glacial North Atlantic and North Pacific oceans, Nature, 360, 249-251, doi: $10.1038 / 360249 \mathrm{a} 0$.

Sánchez, R. F., and P. Relvas (2003), Spring-summer climatological circulation in the upper layer in the region of Cape St.Vincent, southwest Portugal, ICES J. Mar. Sci., 60, 12321250, doi:10.1016/S1054-3139(03)00137-1.

Sánchez Goñi, M. F., F. Eynaud, J. L. Turon, and N. J. Shackleton (1999), High resolution palynological record off the
Iberian margin: Direct land-sea correlation for the Last Interglacial complex, Earth Planet. Sci. Lett., 171, 123-137, doi:10.1016/S0012-821X(99)00141-7.

Sánchez Goñi, M.-F., J.-L. Turon, F. Eynaud, and S. Gendreau (2000), European climatic response to millennial-scale changes in the atmosphere-ocean system during the Last Glacial Period, Quat. Res., 54, 394-403, doi:10.1006/ qres.2000.2176.

Sánchez Goñi, M.-F., I. Cacho, J.-L. Turon, J. Guiot, F. J. Sierro, J.-P. Peypouquet, J. O. Grimalt, and N. J. Shackleton (2002), Synchroneity between marine and terrestrial responses to millennial scale climatic variability during the last glacial period in the Mediterranean region, Clim. Dyn., 19, 95-105, doi:10.1007/s00382-001-0212-X.

Sánchez Goñi, M.-F., A. Landais, W. J. Fletcher, F. Naughton, S. Desprat, and J. Duprat (2008), Contrasting impacts of Dansgaard-Oeschger events over a western European latitudinal transect modulated by orbital parameters, Quat. Sci. Rev., 27, 1136-1151, doi:10.1016/j.quascirev. 2008.03.003.

Sarnthein, M., et al. (1995), Variations in Atlantic surface ocean paleoceanography, $50^{\circ}-80^{\circ} \mathrm{N}$ : A time-slice record of the last 30,000 years, Paleoceanography, 10, 1063-1094, doi:10.1029/95PA01453.

Sarnthein, M., R. Gersonde, S. Niebler, U. Pflaumann, R. Spielhagen, J. Thiede, G. Wefer, and M. Weinelt (2003), Overview of glacial Atlantic ocean mapping (GLAMAP 2000), Paleoceanography, 18(2), 1030, doi:10.1029/ 2002PA000769.

Schönfeld, J., and R. Zahn (2000), Late Glacial to Holocene history of the Mediterranean Outflow. Evidence from benthic foraminiferal assemblages and stable isotopes at the Portuguese margin, Palaeogeogr. Palaeoclimatol. Palaeoecol., 159(1-2), 85-111, doi:10.1016/S0031-0182(00)00035-3.

Schönfeld, J., R. Zahn, and L. de Abreu (2003), Surface and deep-water response to rapid climate changes at the Western Iberian Margin, Global Planet. Change, 36(4), 237-264, doi:10.1016/S0921-8181(02)00197-2.

Shackleton, N. J., M. A. Hall, and E. Vincent (2000), Phase relationships between millennial-scale events 64,000 24,000 years ago, Paleoceanography, 15, 565-569, doi:10.1029/2000PA000513.

Shackleton, N. J., R. G. Fairbanks, T. Chiu, and F. Parrenin (2004), Absolute calibration of the Greenland time scale: Implications for Antarctic time scales and for $\delta^{14} \mathrm{C}$, Quat. Sci. Rev., 23, 1513-1523, doi:10.1016/j.quascirev. 2004.03.006.

Sierro, F. J., et al. (2005), Impact of iceberg melting on Mediterranean thermohaline circulation during Heinrich events, Paleoceanography, 20, PA2019, doi:10.1029/ 2004PA001051.

Skinner, L. C., and H. Elderfield (2005), Constraining ecological and biological bias in planktonic foraminiferal $\mathrm{Mg} / \mathrm{Ca}$ and $\delta^{18} \mathrm{O}_{\mathrm{cc}}$ : A multispecies approach to proxy calibration testing, Paleoceanography, 20, PA1015, doi:10.1029/ 2004PA001058.

Skinner, L. C., and H. Elderfield (2007), Rapid fluctuations in the deep North Atlantic heat budget during the last glacial period, Paleoceanography, 22, PA1205, doi:10.1029/ 2006PA001338.

Smith, K. L.Jr., B. H. Robison, J. J. Helly, R. S. Kaufmann, H. A. Ruhl, T. J. Shaw, B. S. Twining, and M. Vernet (2007), Free-drifting icebergs: Hot spots of chemical and biological enrichment in the Weddell Sea, Science, 317, 478-482, doi:10.1126/science.1142834. 
Sousa, F., and A. Bricaud (1992), Satellite-derived phytoplankton structures in the Portuguese upwelling area, J. Geophys. Res., 97(C7), 11,343-11,356, doi:10.1029/ 92JC00786.

Steffensen, J. P., et al. (2008), High resolution Greenland ice core data show abrupt climate change happens in few years, Science, 321, 680-684, doi:10.1126/science.1157707.

Sverdrup, H. U., M. W. Johnson, and R. W. Fleming (1942), The Oceans: Their Physics, Chemistry and General Biology, 1060 pp., Prentice-Hall, Englewood, N. J.

Tchernia, P. (1978), Océanographie Régionale, Description Physique des Océans et des Mers, 257 pp., Ecole Natl. Supér. des Tech. Avancées, Paris.

Thomson, J., S. Nixon, C. P. Summerhayes, J. Schönfeld, R. Zahn, and P. Grootes (1999), Implications for sedimentation changes on the Iberian margin over the last two glacial/interglacial transitions from $\left({ }^{230} \mathrm{Th}_{\text {excess }}\right)_{0}$ systematics, Earth Planet. Sci. Lett., 165, 255-270, doi:10.1016/S0012-821X(98)00265-9.

Thomson, J., S. Nixon, C. P. Summerhayes, E. J. Rohling, J. Schönfeld, R. Zahn, P. Grootes, F. Abrantes, L. Gaspar, and S. Vaqueiro (2000), Enhanced productivity on the Iberian margin during glacial/interglacial transitions revealed by barium and diatoms, J. Geol. Soc., 157, 667-677.

Thouveny, N., E. Moreno, D. Delanghe, L. Candon, Y. Lancelot, and N. J. Shackleton (2000), Rock magnetic detection of distal ice-rafted debris: Clue for the identification of Heinrich layers on the Portuguese margin, Earth Planet. Sci. Lett., 180, 61-75, doi:10.1016/S0012-821X(00)00155-2.

Toucanne, S., T. Mulder, J. Schönfeld, V. Hanquiez, E. Gonthier, J. Duprat, M. Cremer, and S. Zaragosi (2007), Contourites of the Gulf of Cadiz: A high-resolution record of the paleocirculation of the Mediterranean outflow water during the last 50,000 years, Palaeogeogr. Palaeoclimatol. Palaeoecol., 246, 354-366, doi:10.1016/j.palaeo.2006.10.007.

Turon, J.-L. (1984), Direct land/sea correlations in the last interglacial complex, Nature, 309, 673-676, doi:10.1038/ $309673 \mathrm{a} 0$

Turon, J.-L., and L. Londeix (1988), Les asssemblages de kystes de dinoflagellés en Méditerranée occidentale (Mer d'Alboran): Mise en evidence de l'évolution des paléoenvironnement depuis le dernier maximum glaciaire, Bull. Cent. Rech. Explor. Prod. Elf Aquitaine, 12, 313-344.
Turon, J.-L., A.-M. Lézine, and M. Denèfle (2003), Land-sea correlations for the last glaciation inferred from a pollen and dinocyst record from the Portuguese margin, Quat. Res., 59, 88-96, doi:10.1016/S0033-5894(02)00018-2.

Vautravers, M., and N. J. Shackleton (2006), Centennial-scale surface hydrology off Portugal during marine isotope stage 3: Insights from planktonic foraminiferal fauna variability, Paleoceanography, 21, PA3004, doi:10.1029/ 2005PA001144.

Vidal, L., L. Labeyrie, E. Cortijo, M. Arnold, E. Michel, S. Becquey, J. C. Duplessy, and T. C. E. van Weering (1997), Evidence for changes in the North Atlantic Deep Water linked to the Heinrich events, Earth Planet. Sci. Lett., 146, 13-27, doi:10.1016/S0012-821X(96)00192-6.

Voelker, A. H. L., S. M. Lebreiro, J. Schönfeld, I. Cacho, H. Erlenkeuser, and F. Abrantes (2006), Mediterranean outflow strengthening during Northern Hemisphere coolings: A salt source for the glacial Atlantic?, Earth Planet. Sci. Lett., 245, 39-55, doi:10.1016/j.eps1.2006.03.014.

Waelbroeck, C., S. Mulitza, H. Spero, T. Dokken, T. Kiefer, and E. Cortijo (2005), A global compilation of late Holocene planktonic foraminiferal $\delta^{18} \mathrm{O}$ : Relationship between surface water temperature and $\delta^{18} \mathrm{O}$, Quat. Sci. Rev., 24, 853-868, doi:10.1016/j.quascirev.2003.10.014.

Wang, Y. L., H. Cheng, R. L. Edwards, Z. S. An, J. Y. Wu, C.C. Shen, and J. A. Dorale (2001), A high-resolution absolute-dated Late Pleistocene monsoon records from Hulu Cave, China, Science, 294(5550), 2345-2348, doi:10.1126/science.1064618.

Zahn, R., J. Schönfeld, H.-R. Kudrass, M.-H. Park, H. Erlenkeuser, and P. Grootes (1997), Thermohaline instability in the North Atlantic during meltwater events: Stable isotope and ice-rafted detritus records from core SO75-26KL, Portuguese margin, Paleoceanography, 12, 696-710, doi:10.1029/97PA00581.

Zaragosi, S., F. Eynaud, C. Pujol, G. A. Auffret, J. L. Turon, and T. Garlan (2001), Initiation of European deglaciation as recorded in the northwestern Bay of Biscay slope environments (Meriadzek Terrace and Trevelyan Escarpment): A multi-proxy approach, Earth Planet. Sci. Lett., 188, $493-$ 507, doi:10.1016/S0012-821X(01)00332-6. 